NBER WORKING PAPER SERIES

\title{
ON THE FUNDAMENTAL RELATION BETWEEN EQUITY RETURNS AND INTEREST RATES
}

\author{
Jaewon Choi \\ Matthew P. Richardson \\ Robert F. Whitelaw \\ Working Paper 20187 \\ http://www.nber.org/papers/w20187
}

\author{
NATIONAL BUREAU OF ECONOMIC RESEARCH \\ 1050 Massachusetts Avenue \\ Cambridge, MA 02138 \\ June 2014
}

We thank Jennifer Carpenter, Charles Cao, Scott Joslin, Weina Zhang, and seminar participants at the Chicago Booth Junior Finance Symposium, Copenhagen Business School, Lund University, New York University, Tsinghua University, University of North Carolina, University of Illinois, Vienna University of Economics and Business, the 2013 Singapore International Conference on Finance, and the 2012 Financial Research Association Meeting for helpful comments. Ji Min Park provided excellent research assistance. The views expressed herein are those of the authors and do not necessarily reflect the views of the National Bureau of Economic Research.

NBER working papers are circulated for discussion and comment purposes. They have not been peerreviewed or been subject to the review by the NBER Board of Directors that accompanies official NBER publications.

(C) 2014 by Jaewon Choi, Matthew P. Richardson, and Robert F. Whitelaw. All rights reserved. Short sections of text, not to exceed two paragraphs, may be quoted without explicit permission provided that full credit, including (C) notice, is given to the source. 
On the Fundamental Relation Between Equity Returns and Interest Rates

Jaewon Choi, Matthew P. Richardson, and Robert F. Whitelaw

NBER Working Paper No. 20187

June 2014

JEL No. G12,G13,G32

\section{ABSTRACT}

This paper uses contingent claim asset pricing and exploits capital structure priority to better understand the relation between corporate security returns and interest rate changes (i.e., duration). We show theoretically and, using a novel dataset, confirm empirically that lower priority securities in the capital structure, such as subordinated or distressed debt and equity, have low or even negative durations because these securities are effectively short higher priority, high duration fixed rate debt. This finding has important implications for interpreting existing results on (i) the time-varying correlation between the aggregate stock market and government bonds, (ii) the use of bond factors for multifactor asset pricing models and forecasting bond and stock returns, (iii) the Fisher effect and inflation, and (iv) the betas of corporate bonds.

\author{
Jaewon Choi \\ Department of Finance \\ jaewchoi@illinois.edu \\ Matthew P. Richardson \\ Stern School of Business \\ New York University \\ 44 West 4th Street, Suite 9-190 \\ New York, NY 10012 \\ and NBER \\ mrichar0@stern.nyu.edu
}

\author{
Robert F. Whitelaw \\ New York University \\ Stern School of Business \\ 44 West 4th Street, Suite 9-190 \\ New York, NY 10012-1126 \\ and NBER \\ rwhitela@stern.nyu.edu
}




\section{Introduction}

There has been a plethora of research in finance that investigates the comovement properties of stock and bond returns. Surprisingly, the fundamental relation between these asset returns has been difficult to pin down. Part of the problem is that common covariation between stocks and bonds can derive from shocks to real and nominal aggregate cash flows, ${ }^{1}$ changing expected returns, ${ }^{2}$ or, in light of the lack of success of some of these asset pricing models, aggregate behavioral phenomena. ${ }^{3}$ In particular, a number of papers have tried to explain the periods in which equity returns and bond returns have been negatively correlated. From a theoretical point of view, while the engine underlying the consumption-based asset pricing paradigm links all long-term securities through a common pricing factor, the underlying models can be tweaked to generate different relationships between stock and bond returns. ${ }^{4}$

This paper takes a different approach to the question of why stock and bond markets can move in opposite directions. In contrast to standard explanations, which relate business cycles to aggregate comovements in bond and equity markets, this paper appeals to structural models of capital structure valuation (in the spirit of Merton (1974)). Even under the assumption of independence between the value of a firm's assets and market interest rates, one would expect lower priority securities in the capital structure, such as subordinated or distressed debt and equity, to have low or even negative durations. Intuitively, the lower priority securities are effectively short higher priority fixed rate debt, i.e., they are short the bond market.

\footnotetext{
${ }^{1}$ See Fama and Schwert (1977), Barsky (1989), Campbell and Ammer (1993), Fama and French (1993), and Boudoukh, Richardson, and Whitelaw (1994), among others, for theoretical and empirical investigations of common factors driving both stock and bond returns.

${ }^{2}$ See, for example, Keim and Stambaugh (1986), Fama and French (1989), and Campbell and Cochrane (1999), among others, for both empirical and theoretical descriptions of joint stock and bond return predictability.

${ }^{3}$ See Shiller and Beltratti (1992), Connolly, Stivers, and Sun 92005), Baele, Bekaert, and Inghelbrecht (2010) and Baker and Wurgler (2012) for an analysis of non-fundamental determinants of the stock and bond return covariation.

${ }^{4}$ See Campbell (2000), Campbell, Sunderam and Viceira (2013) and Koijen, Lustig, and Van Nieuwerburgh (2012) for examples of such asset pricing models.
} 
Because aggregate stock indices, such as the Dow Jones 30 and S\&P 500, are simply weighted portfolios of the underlying stocks, which in turn are governed by this priority structure, the aggregate stock index returns will ceteris paribus tend to move negatively with long-term bond returns. As an illustration of this effect, Figure 1 below graphs 3-year rolling correlations over the past three decades between interest rate changes and monthly returns on several bond indices (i.e., government, investment grade, and high yield) and an equity index (i.e., the S\&P500). As can be seen from the figure, while the correlation pattern varies over time, there is a consistent ordering of these correlations in line with implications from the priority rules of a firm's capital structure. That is, correlations increase (durations decrease) as we move from government bonds, to high priority investment grade debt, and finally to low priority, high yield debt and equity.

\section{FIGURE 1}

The figure plots return correlations of various return series (the S\&P 500 index and high yield, investment grade and Treasury bond indices drawn from Citigroup's Yieldbook) with changes in fiveyear, constant maturity Treasury yields. The correlations are estimated over 36-months rolling windows using monthly returns.

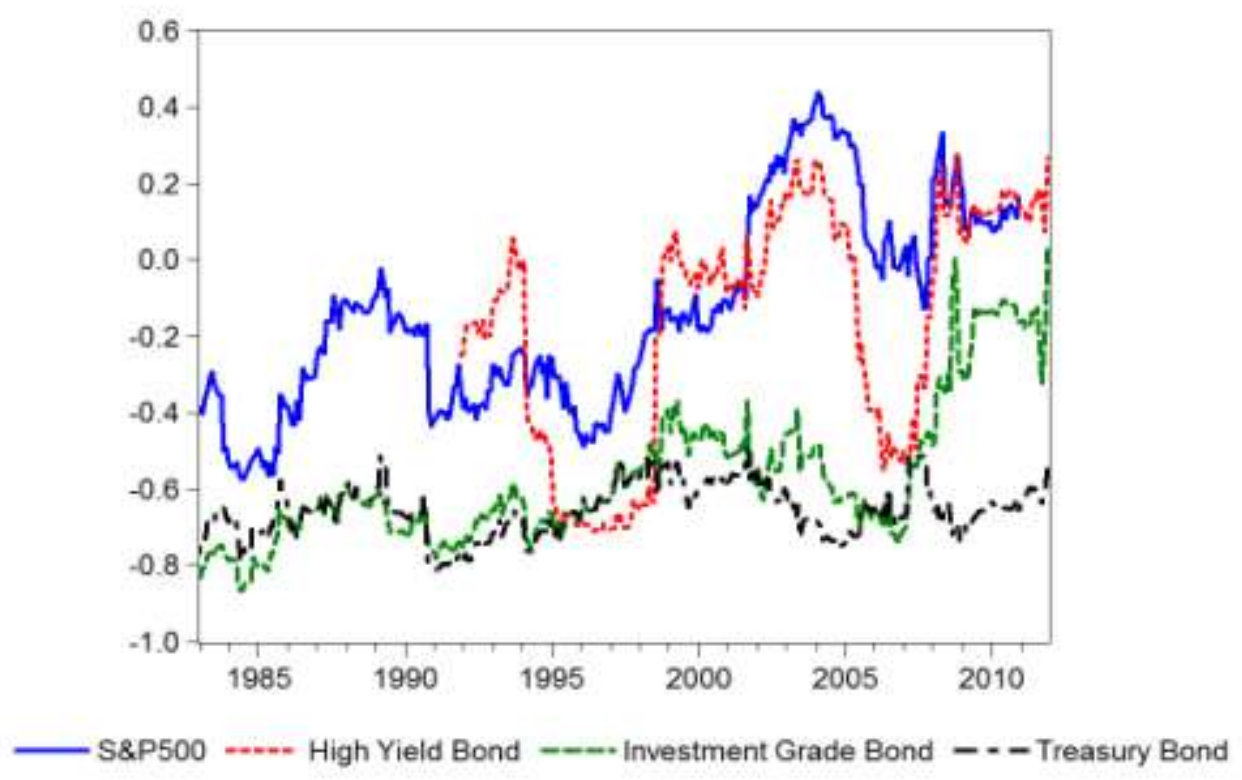

The contribution of this paper is twofold. First, we document empirically the degree to which the priority structure of the firm's capital structure can help explain the relation between interest rates and corporate bond and equity returns using two distinct analyses. Using a novel dataset in which the priority structure has been mapped firm by firm, we confirm the 
underlying theoretical result that this priority structure is an important determinant of the relation between security returns and interest rates. We further highlight this effect by comparing equity indices sorted on their degree of leverage, and, controlling for industry effects, show their interest rate sensitivity patterns. In particular, we document the more levered the index, the more negative the sensitivity of index returns to bond returns.

Second, and more generally, the paper emphasizes the importance of modeling equity as a claim against the assets of the firm that is also short the firm's debt. Though this point is simple, it has implications for the relation between stock returns and interest rates that are rarely, if ever, investigated in the finance literature. Since high priority debt has positive duration, equity has negative duration by construction. This result holds by no arbitrage and is a truism. Any time-varying covariation between the firm's assets and interest rates can simply be added to this baseline negative relation. We provide several examples from the literature which show the practical importance of modeling equity returns this way. Specifically, we look at (i) the time-varying covariation between aggregate stock indices and bonds, (ii) the use of term premiums and default spreads to explain time-varying expected returns, (iii) the question of whether stocks are a hedge against inflation, and (iv) the betas of corporate bonds.

The paper proceeds as follows. In Section II, we review the basic theory of the firm as put forth by Merton (1974) and Chance (1990), extended to a stochastic interest rate environment as in Rabinovitch (1989), for example. This literature shows that defaultable bonds not only have shorter lives and thus less interest rate sensitivity, but more so that lower priority bonds and equity, in particular, are effectively short higher priority debt. We describe the implications of this result in terms of the aggregate returns on different asset classes. Section III introduces the data and some stylized facts, suggestive of the theory. We then present the main empirical results of the paper. In particular, we provide both a firm-by-firm and aggregate analysis of the relation between security returns and interest rate changes implied by the priority of a firm's capital structure. Section IV shows the importance of these results for understanding and analyzing well-known phenomena documented in the finance literature. Section V concludes. 


\section{Theory}

In this section, we briefly review the relevant literature on pricing contingent claims on the assets of a firm and the role of interest rates. The analysis follows Merton (1974) and Chance (1990). We make the standard assumptions of Merton (1974), e.g., the firm's underlying assets follow a Brownian motion; there are no transactions costs, information asymmetries or taxes so that the Modigliani-Miller theorem obtains; there is continuous trading; and investors can borrow and lend at the same rate. In addition, we allow for stochastic interest rates, where the shock to interest rates can be correlated with innovations to the value of the firm's assets. In this framework, we show how the contingent claims on the firm's assets, such as equity, subordinated debt and senior debt, are priced given changes in interest rates.

Assume the (nominal) value of the firm's asset $\left(V_{t}\right)$ follows the process

$$
d V_{t}=r_{t} V_{t} d t+\sigma_{V} V_{t} d Z_{t}
$$

where $r_{t}$ is the instantaneous (nominal) risk-free rate, $\sigma_{V}$ is the volatility of the firm's assets, and $Z_{t}$ is a standard Brownian motion under the risk neutral measure. ${ }^{5}$ As in Vasicek (1977), we further assume that $r_{t}$ follows the mean-reverting process

$$
d r_{t}=q\left(m-r_{t}\right) d t+v d W_{t}
$$

where $q$ is the speed of mean reversion and $m$ is the long run mean of the interest rate. $W_{t}$ is a standard Brownian motion under the risk neutral measure. ${ }^{6}$ The correlation between the shocks in the two Brownian motions is $\rho$, i.e., $d Z_{t} \cdot d W_{t}=\rho d t$. This correlation captures the interest rate sensitivity of assets, i.e., asset duration.

Following Merton (1973) and Rabinovitch (1989), the price of a put option written on the firm's assets is

\footnotetext{
${ }^{5}$ The risk premium on the assets is irrelevant for the results that follow, so for ease of exposition all calculations are done under the risk neutral measure.

${ }^{6}$ Many of the pricing results to follow can be derived under much more general assumptions about the processes for asset values and interest rates (see, for example, Acharya and Carpenter (2002)), but these particular assumptions allow for a simple presentation of the relevant intuition.
} 


$$
\begin{aligned}
& P\left(V, K, \tau, r, \sigma_{V}\right)=K \cdot B(\tau, r) \cdot N\left(-d_{2}\right)-V \cdot N\left(-d_{1}\right) \\
& B(r, \tau)=A e^{-r C} \\
& A=e^{k(C-\tau)-(v C / 2)^{2} / q} \\
& C=\left(1-e^{-q \tau}\right) / q
\end{aligned}
$$

where $K$ is the strike price, $\tau$ is the maturity of the option, and $k$ is a constant defined as $k=m-(v / q)^{2} / 2 . B(\tau, r)$ is the price of a default-free zero coupon bond of the same maturity $\tau$. The arguments $d_{1}$ and $d_{2}$ in the cumulative normal distribution function $N(\cdot)$ are defined as

$$
\begin{aligned}
& d_{1}=\frac{\ln (V /(K \cdot B(r, \tau)))+T / 2}{\sqrt{T}} \\
& d_{2}=d_{1}-\sqrt{T} \\
& T=\sigma^{2} \tau+\left(\tau-2 C+\left(1-e^{-2 q \tau}\right) /(2 q)\right)(v / q)^{2}-(2 \rho \sigma(\tau-C) v) / q
\end{aligned}
$$

Using the above valuation, we can price various contingent claims on the firm. For simplicity and to build intuition, we assume that the firm's claims are separated into three classes of financial assets - equity (denoted $E$ ), zero-coupon senior debt with face value $K_{s}$ and maturity $\tau$ (denoted $D_{s}$ ) and zero-coupon junior debt with face value $K_{j}$ and maturity $\tau$ (denoted $D_{j}$ ). Under these assumptions, and under a strict absolute priority rule, it is well known that the prices of these financial assets can be expressed in terms of options on the underlying assets of the firm and a default-free zero coupon bond:

$$
\begin{aligned}
& D_{s}=K_{s} B(\tau, r)-P\left(V, K_{s}, \tau, r, \sigma_{V}\right) \\
& D_{j}=K_{j} B(\tau, r)+P\left(V, K_{s}, \tau, r, \sigma_{V}\right)-P\left(V, K_{s}+K_{j}, \tau, r, \sigma_{V}\right), \\
& E=V+P\left(V, K_{s}+K_{j}, \tau, r, \sigma_{V}\right)-\left(K_{s}+K_{j}\right) B(\tau, r)
\end{aligned}
$$

where $P($.$) is the value of a European put given above. Senior debt equals a default-free zero$ coupon bond minus a put option on the underlying assets with an exercise price equal to its face value $K_{s}$. Junior debt equals a default-free bond minus the difference of two put options on the underlying assets, with exercise prices equal to $K_{s}+K_{j}$ and $K_{s}$. Equity is simply the value of the assets minus the value of zero coupon debt with a face value equal to $K_{s}+K_{j}$, i.e., a default-free bond minus a put option on the underlying assets with an exercise price equal to the face value $K_{s}+K_{j}$. The key finding is that equity takes on a short position in the 
underlying debt and therefore has a tendency to increase in value with positive interest rate changes.

We define interest rate sensitivity, or modified duration, as the negative of the coefficient in a regression of the percentage changes in prices on changes in the instantaneous interest rate, i.e., the continuous time counterpart of the discrete time regressions we run later in the paper. ${ }^{7}$ One can also view this quantity as the magnitude of the short position in interest rates necessary to hedge the interest rate exposure of the security. Under this definition, the modified duration of the firm's assets is

$$
\operatorname{Dur}(V) \equiv-\frac{\operatorname{cov}\left(\frac{d V_{t}}{V_{t}}, d r_{t}\right)}{\operatorname{var}\left(d r_{t}\right)}=-\frac{\rho \sigma_{V}}{v}
$$

For the senior bond, modified duration is

$$
\begin{aligned}
\operatorname{Dur}\left(D_{s}\right) & \equiv-\frac{\operatorname{cov}\left(\frac{d D_{s}}{D_{s}}, d r\right)}{\operatorname{var}(d r)} \\
& =-\frac{\operatorname{cov}\left(\frac{\partial D_{s}}{\partial V} \frac{V}{D_{s}} \sigma_{V} d Z+\frac{\partial D_{s}}{\partial r} \frac{1}{D_{s}} v d W, v d W\right)}{\operatorname{var}(v d W)} \\
& =-\frac{\partial D_{s}}{\partial V} \frac{V}{D_{s}} \frac{\rho \sigma_{V}}{v}-\frac{\partial D_{s}}{\partial r} \frac{1}{D_{s}}
\end{aligned}
$$

where $d D_{s} / D_{s}$ is obtained from Ito's formula. The modified durations of the junior bond and equity are defined similarly:

$$
\begin{gathered}
\operatorname{Dur}\left(D_{j}\right)=-\frac{\partial D_{j}}{\partial V} \frac{V}{D_{j}} \frac{\rho \sigma_{V}}{v}-\frac{\partial D_{j}}{\partial r} \frac{1}{D_{j}} \\
\operatorname{Dur}(E)=-\frac{\partial E}{\partial V} \frac{V}{E} \frac{\rho \sigma_{V}}{v}-\frac{\partial E}{\partial r} \frac{1}{E}
\end{gathered}
$$

\footnotetext{
${ }^{7}$ Since we are working in a 1 -factor interest rate world, we could easily redefine this duration with respect to the yields on risk-free bonds at any maturity with similar results.
} 
Note that in this setting the durations of the contingent claims consist of two components.

The first term is the asset duration $\left(-\frac{\rho \sigma_{V}}{v}\right)$ multiplied by the elasticity of the claim with respect to the assets, e.g., $\left(\partial D_{s} / D_{s}\right) /(\partial V / V)$ in the case of the senior bond. This term captures how the asset duration transfers to a contingent claim, which indicates that it may be necessary to control for the duration of assets in our empirical analysis if asset durations differ significantly from zero. The second term is the interest rate sensitivity of the claim, holding asset value fixed. By definition, the duration of the assets is the weighted sum of the durations of the claims on the assets of the firm

$$
\frac{E}{V} \operatorname{Dur}(E)+\frac{D_{s}}{V} \operatorname{Dur}\left(D_{s}\right)+\frac{D_{j}}{V} \operatorname{Dur}\left(D_{j}\right)=\operatorname{Dur}(V)=-\frac{\rho \sigma_{V}}{v}
$$

To understand how dynamic covariation between contingent claim returns and interest rate changes can arise, Figure 2 graphs the modified durations of senior debt, junior debt and equity as a function of the firm's asset value relative to the face value of debt outstanding for various values of asset duration (achieved by changing the correlation, $\rho$ ). ${ }^{8}$

Several observations are in order. First, when the value of the assets $V$ is large relative to $K_{s}+K_{j}$, the senior and junior debt both have modified durations equal to the modified duration of a default-free bond with the same maturity. (Note that the modified duration of a defaultfree bond is less than its maturity because we define duration relative to the instantaneous interest rate, which is mean reverting in the Vasicek model.)

Second, and of particular importance, there is a general ordering of modified durations from senior debt to junior debt to equity. The direction of this ordering depends on whether the duration of the assets exceeds that of the senior debt when it is risk-free. If it does not, which we consider to be the more likely case empirically, then duration declines as the claim becomes more junior as illustrated in the first 3 cases in Figure 2 (asset durations of -2, 0 and 2). The intuition is that the second component of duration derived above dominates, i.e., what

\footnotetext{
${ }^{8}$ For illustrative purposes, we choose $r=5 \%, \sigma_{v}=20 \%, \tau=5, K_{s}=25, K_{j}=25, q=0.20$, $v=2 \%$, and $m=7 \%$.
} 
matters is the direct interest rate sensitivity of the various claims. Considering only this component, senior debt always has a positive duration (i.e., negative interest rate sensitivity) while equity always has a negative duration (i.e., positive interest rate sensitivity). The sign of the duration for junior debt is ambiguous, depending on the degree of leverage of the firm as measured by $V$ relative to $K_{s}$ and $K_{s}+K_{j}$. Adding a non-zero asset duration of a sufficiently small magnitude does not change the ordering, but it changes the durations to which the claims converge, i.e., equity duration converges to asset duration as firm value increases, and senior debt duration converges to asset duration as firm value decreases. Moreover, negative (positive) asset durations increase (decrease) the duration spread between the claims because the asset duration effect works in the same (opposite) direction as the direct interest rate sensitivity.

\section{FIGURE 2}

This figure plots the modified durations of senior debt, junior debt, and equity for the model given in equations (1) and (2). The parameter values are $r=5 \%, \sigma_{v}=20 \%, \tau=5, K_{s}=25, K_{j}=25$, $q=0.20, v=2 \%$, and $m=7 \%$.
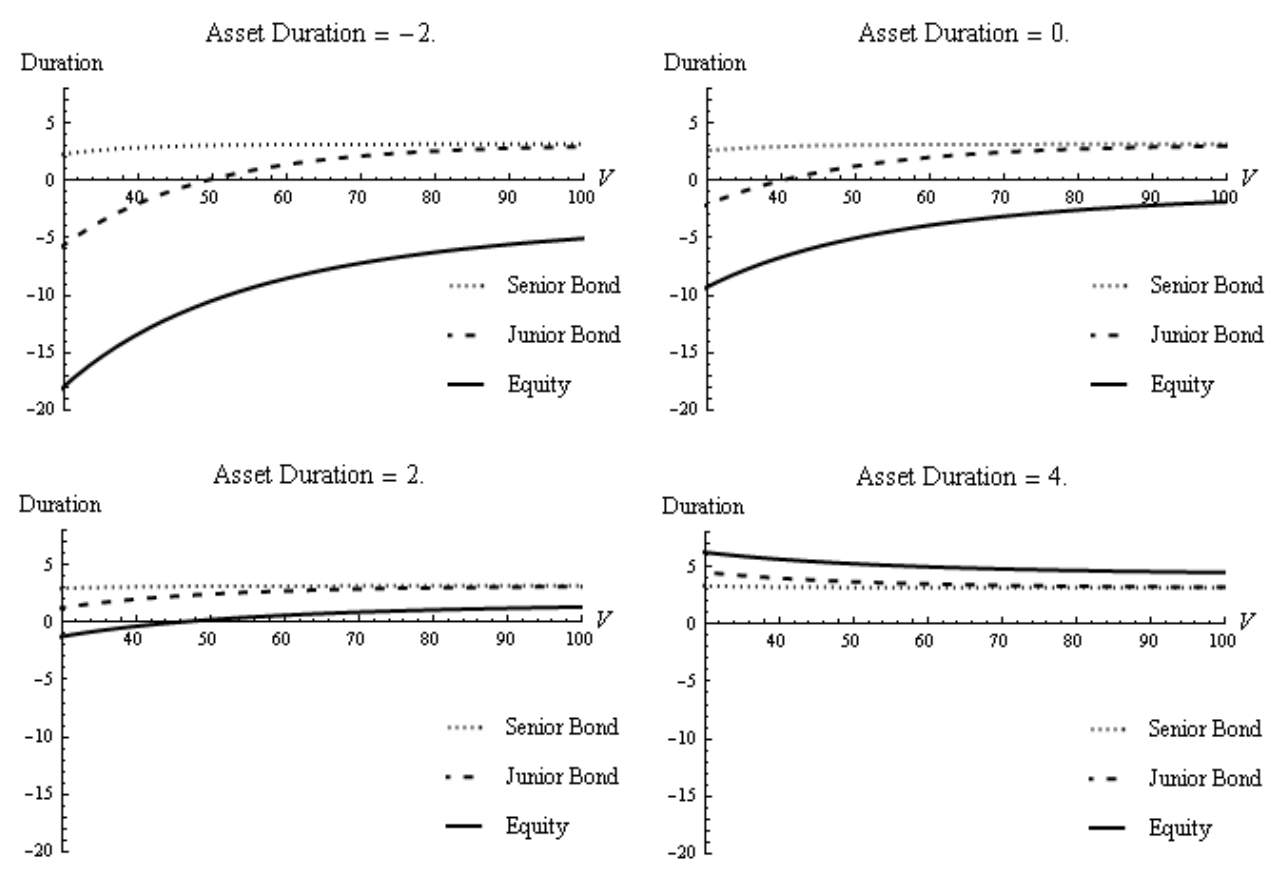
In the extreme case when the asset duration exceeds to duration of the risk-free senior debt, then the ordering is reversed. The asset duration effect dominates and the lower priority claims are more exposed to this effect.

Note that since the modified duration of a portfolio of financial assets is just a market valueweighted sum of the modified durations of these assets, popular indices such as the S\&P 500, the Dow Jones 30, and various corporate bond indices will take on the sensitivities of the underlying financial assets. Therefore, Figure 2 shows that there is naturally a negative relation between stock return index returns and government bond returns induced by the capital structure of firms. The magnitude of this negative relation will depend on the crosssectional relation between firms' leverage ratios and their relative market values, and it will also be affected by the duration of the underlying assets.

From an ex ante point of view, it is not clear what should be the value of this underlying asset duration. To build some intuition, consider a standard, representative agent, consumptionbased equilibrium model with i.i.d. consumption and dividend growth and money neutrality, i.e., no real effects of inflation. In this setting, real asset returns are a function of contemporaneous consumption growth and real interest rates are constant. With money neutrality, the Fisher effect holds, and nominal asset values increase with inflation (e.g., see Fama and Schwert (1977) and Boudoukh and Richardson (1994)). Nominal asset returns therefore move one for one with current inflation. If inflation is persistent, however, an increase in inflation would also lead to an increase in expected inflation in the same direction, leading to an increase in interest rates. Thus, in this standard framework, there is a positive correlation between interest rates and asset values, or, in other words, a tendency towards negative duration. This asset duration effect is independent of the fact that stocks, as levered claims on assets, will tend to have negative duration due to being short positive duration bonds.

There are reasons why this result may not hold in a more complex setting. For example, there is a well known literature that argues that inflation covaries with real economic activity, thus leading to a negative relation between nominal asset values and inflation (e.g., see Fama 
(1981), Boudoukh, Richardson, and Whitelaw (1993), Campbell, Sunderam, and Viceira (2013), and Bekaert and Engstrom (2010)). In this case, changes in inflation could lead to changes in the opposite direction in interest rates and asset values.

More generally, there is now an extensive literature that models the joint behavior of asset prices and interest rates in dynamic consumption-based asset pricing models (e.g., Barsky (1989), Campbell and Cochrane (1999), and Koijen, Lustig, and Van Nieuwerburgh (2012), among others). While many of these models also produce results more consistent with negative asset durations, it is possible to generate the opposite (e.g., Shiller and Beltratti (1992) and Campbell, Sunderam, and Viceira (2013)). ${ }^{9}$ Some of these theoretical models are motivated by empirical results that show a time-varying and nonzero relation between equity returns and interest rate changes. However, Figure 2 shows that this relation exists even if asset duration is zero.

There is a fairly extensive empirical literature over the past three decades analyzing contingent claim pricing models of the firm. The evidence in these studies is mixed at best. The earliest paper in this area, Jones, Mason and Rosenfeld (1984), documents disappointing results. To a large extent, these findings have been confirmed in various ways by CollinDufresne, Goldstein, and Martin (2001), Eom, Helwege, and Huang (2004) and Bharath and Shumway (2008), among others. These authors find that a number of implications of contingent claim pricing of corporate liabilities are not borne out in the data. That said, other papers take exception to this conclusion, e.g., Ericsson, Jacobs, and Oviedo (2005). Moreover, several papers find some support for the theory, in particular, by documenting comovements between equity returns and higher yielding bonds (e.g., Blume, Keim, and Patel (1991) and Schaefer and Strebulaev (2008)). Our paper focuses on a specific aspect of contingent claim pricing, namely the exposure of different securities within the capital structure to interest rate changes, i.e., duration. The rest of this paper focuses on measuring the modified durations of these financial assets in light of the above theory and reinterpreting

\footnotetext{
${ }^{9}$ Note that these models do not model the value of equity as a contingent claim on the underlying assets of the firm. One could interpret these papers as pricing unlevered equity.
} 
existing results that tend to ignore the implications of the contingent claims approach for the relation between equity returns and interest rate changes.

\section{Evidence}

In this section, we empirically investigate the relevance of contingent claim pricing of equity and corporate debt for understanding the comovement of these asset classes with interest rates. Our strategy is as follows. First, to the extent possible, we map out the capital structure for each firm in our sample. Second, on a firm-by-firm basis, we analyze the propositions implied by equations (2) and Figure 2. Specifically, at the individual firm level, given a mapped out capital structure, we measure the sensitivity of the particular security's return to interest rates as a function of where it is in the priority structure of the firm. Third, at the aggregate level, under certain assumptions, we show that the interest rate sensitivity of portfolios of security returns is declining in priority, and, holding the sensitivity of asset returns to interest rates constant, show that this sensitivity moves from positive to negative territory.

\section{A. Data Description}

In order to map out the capital structure and construct the returns on a firm's assets, we need to utilize a number of datasets, including (i) CRSP for equity prices, (ii) the Bridge EJV database from Reuters for corporate bond prices and details, ${ }^{10}$ (iii) the FISD from Mergent for additional corporate bond details and verification of the EJV data, (iv) Dealscan and the mark-to-market pricing services from Loan Pricing Corporation for loans, (v) Compustat for the face value of debt and other accounting information, and (vi) Bloomberg for fact checking discrepancies. The construction of the asset return series and the description of the data are provided in detail in Choi (2013). As a result, we only summarize the data and stylized facts relevant for our problem.

\footnotetext{
${ }^{10}$ Each day, the bid and ask prices are gathered from dealers in the marketplace and then aggregated to one set of bid and ask prices. As an indication of its importance in the corporate bond market, most participants use this database to mark their books each day. The bond data requires substantial cleaning, involving issues such as duplication via 144a issuances, staleness and matrix pricing. Choi (2013) provides a detailed analysis of these issues.
} 
Table 1 summarizes the coverage of our sample relative to the usual CRSP/Compustat universe. For the sample period during which we have data on both bonds and loans, Table 1, Panel A shows that our data cover $96.2 \%$ and $89.6 \%$ of the debt structure on an equalweighted and value-weighted basis, respectively. A little over one-third of the capital structure is in the form of loans. Since loans tend to be the highest priority securities and pay floating rates, these loans have little impact on interest rate sensitivity. Panel B documents how many of the firms' capital structures include fixed-rate bonds with multiple priority levels. Specifically, $70.6 \%$ of the capital structures in terms of the number of observations contain bonds of just one priority while $18.6 \%$ have two, $6.2 \%$ three, and $4.6 \%$ four or more. Panel B further breaks down each multi-priority capital structure into low and high priority components as a percentage of total assets. The panel shows that, on average for each firm, there is a nice mix of high and low priority bonds. Panel $\mathrm{C}$ provides the distribution of one key variable in Figure 2, namely the market value of the assets divided by the book value of debt. Over $75 \%$ of the observations involve market assets $25 \%$ greater than the book value of debt.

Assuming that the results of Modigliani and Miller (1958) hold, the firm's assets and liabilities exactly offset, and we can calculate the return on the firm's assets as the weighted average return of its underlying financial claims. In order to calculate these returns, we use the firm's entire capital structure and the corresponding prices and interim payments of the underlying securities. ${ }^{11}$

In terms of each individual component, equity returns are calculated in the usual way as next period's price plus any dividends paid divided by the current price. Bond returns are calculated similarly each period from the quoted bond prices, coupon payments and accrued

\footnotetext{
${ }^{11}$ As shown in Table 1, only a portion of the debt of a company comes in the form of publicly traded bonds. A considerable portion can consist of bank loans. The major sources for the bank loan data are Dealscan (going back to 1987) and, for the pricing and more detailed characteristics of the loans, the Loan Syndications and Trading Association (LSTA) and Loan Pricing Corporation (LPC). There have been some analyses of the quality of the pricing data, most notably Taylor and Sansone (2007). The main conclusion is that, at least for cases where traded prices are available, the average dealer marks are representative. Two drawbacks of the bank loan data are that (i) they are available over a much shorter time period, and (ii) active volume, and thus reliable secondary prices, exist only for leveraged loans. Of course, bank loans of investment grade firms tend to trade around par if their coupon rates float. For the coincident period in which we have access to both bond and loan data, Table 1 shows that over $90 \%$ of the capital structure is covered.
} 
interest. ${ }^{12}$ The more tricky calculation revolves around the returns of bank loans. On the positive side, because bank loans reside towards the top of the capital structure (at least until quite recently), their price variation is not particularly large. ${ }^{13}$ For the sample period in which the loan data are coincident with the bond data, returns are calculated using loan prices and the interest payments over the month. Prior to November 1999 and for a number of firms not covered in the loan pricing dataset, we need to apply an alternative approach to generating loan returns. Specifically, since both the bonds and loans can be viewed as contingent claims on the firm's assets, we run a panel regression, broken down by firm ratings, of the excess return on a firm's bank loans against the excess returns on the firm's bond portfolio and Treasuries (of similar duration to the bonds). These coefficients are then used to matrix price the loans of firms (and for periods) when bank loan data are not available. ${ }^{14}$

As a first pass, Table 2 summarizes estimates of the modified duration for different classes of securities as a function of the value of the assets relative to the debt outstanding. In particular, we estimate the duration of the (i) assets (as constructed above), (ii) higher priority debt issues of medium-term maturity (as long as they cover 10\% of the capital structure and are neither convertible nor callable), (iii) lower priority debt issues of medium-term maturity (as long as they cover 10\% of the capital structure and are neither convertible nor callable), and (iv) equity. These calculations are provided over 5 ranges of $y / \sum_{j} K_{j}$, namely from high leverage to zero leverage.

Table 2 provides a preview of the results to come. Consistent with the theory, across all four ranges that contain levered firms, the durations decrease from the higher priority bonds to the lower priority bonds and finally to equity. However, equity has a positive duration presumably because the assets of the firm have a positive duration. This result will be explored in Subsection B below. Because asset durations vary with leverage across firms, it

\footnotetext{
${ }^{12}$ For the case where a bond price is missing for the month, we interpolate the bond price assuming it changes in relative proportion to other bonds of the firm, the relative change being determined by its relative duration. Interpolation occurs in $0.91 \%$ of the sample.

${ }^{13}$ See, for example, Altman and Stonberg (2006) and Acharya, Hasan, and Saunders (2006) who document very high recovery rates on bank loans and thus low losses given default.

${ }^{14}$ The results are robust to various specifications, most probably due to the relatively low volatility of bank loans.
} 
is difficult to compare the durations of securities across firms that fall into different leverage ranges, yet an important result does emerge. Specifically, consistent with the theory, the bonds have declining duration as $V$ declines relative to the face value of the debt, though this is not true for equity. Equity's duration is increasing from negative to positive, which on the surface contradicts Figure 2. However, asset duration is also increasing, which shows the importance of taking into account the characteristics of the assets, a point we return to in the next subsection.

\section{B. Individual Firm Analysis}

Table 2 is supportive of the theory outlined in Section II. Specifically, there is a monotonic ordering of modified durations of the securities within the capital structure of the firm from positive to negative. This has important implications for understanding the relation between the aggregate returns on broad asset classes and government bonds, a phenomenon that is rarely discussed from this point of view in the literature.

In this subsection, we perform a more detailed analysis of the sensitivity of different asset classes to interest rates by estimating this relation on a firm-by-firm basis. Using firm-byfirm data allows us to isolate the specific priority structure of each firm. Specifically, putting aside the magnitude of asset duration, what matters for a security's interest rate sensitivity is its location within the capital structure of the firm and the relative value of the firm's assets $V$ to its outstanding liabilities. ${ }^{15}$ Therefore, given a mapped out capital structure for each firm, we measure the sensitivity of the particular security's return to interest rates as a function of where it is in the priority structure of the firm.

Table 3 estimates the interest rate sensitivity of bond returns and equity returns. Under the assumption that asset duration is zero, the coefficient of a regression of security returns on interest rate changes will vary with the priority of the security and the "financial health" of the firm (i.e., the market value of its assets relative to the book value of its debt obligations). An important, and relevant, issue is what happens if asset duration is nonzero. For example,

\footnotetext{
${ }^{15}$ Other parameters are also potentially important, such as the volatility of the firm's assets, as these parameters help determine the probability of default.
} 
suppose interest rate changes are proxying for other variables that impact the real value of the firm, i.e., the model is misspecified. This misspecification is a potential problem because if interest rates affect the value of the assets, the impact on the different debt issues and equity will not be proportional but governed by the capital structure. If $V$ is relatively high, and debt is safe, then an increase in asset value due to interest rate changes will accrue primarily to equity. Therefore, it is necessary to employ a functional form in the empirical analysis that incorporates the asset return effect, as well as priority and leverage. Our specification is

$$
\begin{aligned}
R_{t} & =\alpha+\beta_{t} \tau_{t}\left(-\Delta i_{t}\right)+\theta_{t} R A_{t}+\varepsilon_{t} \\
\beta_{t} & =\beta_{0}+\beta_{1} L_{t}+\beta_{2} P_{t}+\beta_{3} L_{t} P_{t}+\beta_{4} Z_{t}, \\
\theta_{t} & =\theta_{0}+\theta_{1} L_{t}+\theta_{2} P_{t}
\end{aligned}
$$

where $\tau_{t}$ is the time-to-maturity of the bond (for equity, the time-to-maturity is set to one); $L_{t}$ is the leverage of the firm defined as log book debt divided by market assets ( $L_{t}=\log \frac{\Sigma K_{i}}{V_{t}}$ ); $P_{t}$ is the priority of the bond defined as one minus the fraction of bonds (face value) that are senior to that bond; $Z_{t}$ is a set of dummy variables for callable, convertible, putable, floating rate and asset-backed bonds; $R A_{t}$ is the return on the firm's assets; and $\Delta i$ is the change in the five-year, constant maturity Treasury yield. (Note that seniority is determined by the relative ratings of bond issues within the firm cross-checked with the individual bond data.) We report pooled estimation results.

The theory says that priority and leverage should matter, and Table 3 basically confirms these predictions. Consider the $2^{\text {nd }}$ column in which we ignore the return on assets. On the bond side, not surprisingly, the duration of bonds is positive and increasing with maturity (the marginal effect being $0.33 \tau$ ). Most important, higher priority bonds have higher duration (the marginal effect being $0.05 P_{t} \tau$ ). In addition to being statistically significant, the estimates are economically meaningful. For example, the average maturity of the bonds in our sample is approximately 6 years; therefore, the seniority of high priority bonds contributes around 0.3 to their duration. Moreover, the greater the leverage, the lower the duration becomes. 
Equation (3) above captures, at least to a first order linear approximation, the theoretical framework of Section II and Figure 2. However, to verify the appropriateness of the functional form of our duration coefficient, Table 4 reports the results from a regression of duration on our specified function of leverage, priority and maturity, using simulated values generated from the theoretical model. Of course, there is no uncertainty embedded in this model, so any deviation from a perfect fit is attributable to the inability of equation (3) to perfectly capture the theoretical setting. The results in Table 4 basically mirror those in Table 3 , albeit with larger magnitudes of both $R^{2} \mathrm{~s}$ and coefficient estimates. For example, the maturity coefficient is positive, the leverage coefficient is negative and the priority coefficient is positive.

On the equity side, column 4 of Table 3 (in which we ignore the return on assets) appears to present a conundrum. Both the duration coefficient and the leverage coefficient are positive, the opposite of the implications of the capital structure theory presented in Section II. This result is consistent with the puzzling finding documented in Table 2 for equity returns. Two observations are in order. First, and somewhat minor, neither of the coefficients is statistically significant. Second, and more important, is the effect of a positive asset duration, which appears to be the case in the data. We then have an omitted variables problem, and, because equity and asset returns are highly correlated, equity will begin to take on the properties of the underlying assets.

Columns 3 and 5 of Table 3 present the results from the estimation of equation (3), controlling for asset returns, which may be affected by interest rates among other factors. As expected, the security returns (i.e., the returns on bonds and stocks) load positively on asset returns. Consider, for example, equity returns. As interest rates change, asset returns increase, hence, increasing equity returns. Without including asset returns in the regression (i.e., column 4), the duration coefficient (i.e., the coefficient on maturity, where maturity is set to one for equity) is misestimated at 0.20 due to the confounding effect of asset returns. With the asset returns included, the coefficient becomes negative at -0.63 . A similar result is documented for the impact of leverage on duration with a switch from 0.06 to -0.18 once asset returns are accounted for. Thus, the results strongly support the priority theory of the 
capital structure for the duration of equity - equity duration is negative and more so for highly levered firms.

With respect to bonds, the new coefficients on interest rate changes given in Column 3 of Table 3 can be interpreted as those conditional on adjusting for all asset return effects, including interest rates. As expected, the basic finding is that including asset returns amplifies the relation between bond returns and interest rate changes.

An alternative way to take out the effect of asset returns is to compare returns across securities of the same firm, thus, somewhat mitigating changes due to variation in the value of the firm's assets. Of course, the control will only be partial due to the securities' different deltas with respect to the assets. Table 5 estimates the interest rate sensitivity of security returns within each firm's capital structure using a difference-in-difference type approach. In other words, to adjust for each firm's overall sensitivity to interest rates and other things such as the asset return misspecification above, we look at the estimates from the regression:

$$
R_{t}^{m}-R_{t}^{n}=\alpha+\beta\left(-\Delta i_{t}\right)+\gamma\left(\tau_{t}^{m}-\tau_{t}^{n}\right)\left(-\Delta i_{t}\right)+\varepsilon_{t},
$$

where $R_{t}^{m}-R_{t}^{n}$ is the return difference between two securities issued by the same firm, with the security $m$ being lower priority than security $n$, and $\tau_{t}^{m}-\tau_{t}^{n}$ is the difference in time-tomaturity between the two securities. When $R_{t}^{m}$ is an equity return, $R_{t}^{n}$ represents the return on all of the fixed-rate bonds of the firm and $\tau_{t}^{m}$ is set to zero.

Table 5 confirms the results of Table 3. Since the coefficient estimates in equation (4) are negative, higher priority debt issues within the firm have a higher duration. Controlling for time to maturity differences barely changes the coefficient, further confirming the result. Similarly, Table 5 shows that equity returns have a lower duration than the fixed rate bonds within the firm. The magnitude of this effect is large, i.e., -1.68 , and is consistent with the theory described by Figure 2. 


\section{Index Level Analysis}

The empirical results of Subsection B above strongly support the importance of capital structure priority in determining the sensitivity of corporate bonds to interest rates. One of the issues with such an analysis, however, is that we performed it at the individual firm level, so many idiosyncratic factors could come into play. It seems worthwhile, therefore, to study portfolios. At the aggregate level, under certain assumptions, one would expect the interest rate sensitivity to be declining in priority, and, holding the sensitivity of asset returns to interest rates constant, would move from the positive to negative territory as we move from high priority debt to equity.

As an initial pass, we construct two portfolios of bonds from similar firms but with different levels of priority in the capital structure. Figure 3 below graphs rolling correlations of the returns on these two portfolios with interest rate changes. As can be seen from the graph, the correlations of the high priority portfolio are more negative (i.e., durations are higher) than those of the low priority portfolio. While the figure also shows the time-varying nature of the correlations, the basic theory underlying the priority structure is again supported.

\section{FIGURE 3}

This figure plots the rolling correlations between interest rate changes and the returns on two portfolios of corporate bonds sorted by their priority.

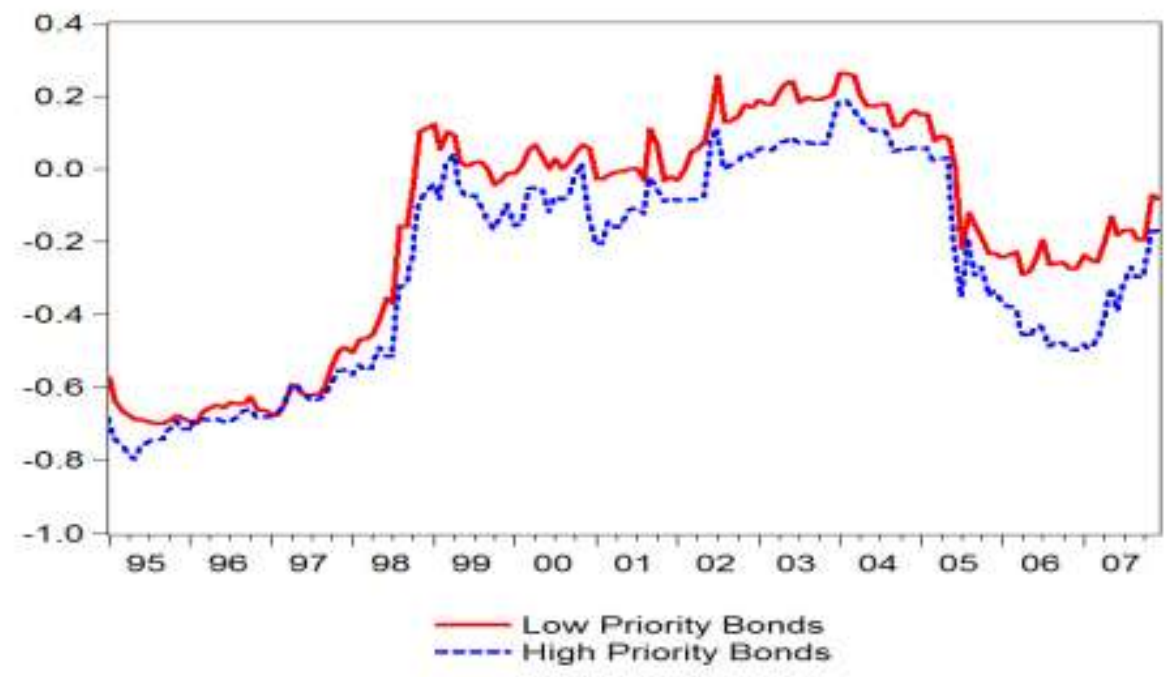


For a more precise analysis, Table 6, Panel A reports duration estimates (i.e., coefficients on $\tau \Delta i$ ) for bond index returns from Citigroup's Yieldbook and issuer-level rating equity portfolio returns. The sample period is from Jan. 1985 to Dec. 2010. The pattern again holds. First, as the issuer rating declines, the duration of the bond portfolio falls. Moreover, for each ratings class, the equity has a lower (or more negative) duration, confirming the ordering between debt and equity. In addition, the equity duration also declines, becoming more negative, as the rating class declines. All of these results are again consistent with the theory of Section II and Figure 2.

In Table 6, Panel B, for each issuer-level rating, bonds are sorted into high and low priority portfolios to get 6-by-2 bond portfolios. Equity portfolios are formed similarly based on ratings. For each ratings class, the high priority bonds have the highest duration, followed by the lower priority bonds, and then finally equity. For example, for A-rated firms, the duration estimates are $3.83,3.80$ and -0.08 , respectively, while for BB-rated firms they are $1.70,1.12$ and -1.76 , respectively.

The results of Section III.B and C strongly support the theory relating the duration of security returns to the security's position within the capital structure and to the current value of the assets relative to the value of the firm's obligations. In the next section, we explore the implications of this fact for some well-known theoretical and empirical findings in the finance literature.

\section{Implications for Aggregate Analysis}

The empirical analysis of Section III provides substantive evidence that the priority of a security within the capital structure of the firm does matter. Consistent with the theory, high priority bonds tend to have higher duration than lower priority bonds within the same firm, and, the asset return-interest rate relation aside, equity has negative duration. Because portfolio returns are simply weighted averages of individual firm returns, these results carry through to the aggregate level. What implications do these results have for well-known 
aggregate phenomena that relate interest rate variables to aggregate stock and bond returns? In this section, we reevaluate some findings from this literature.

\section{A. Comovement of Bond and Equity Returns}

As described above, there is a considerable literature documenting the comovements of stock returns and government bond returns through time (e.g., Campbell and Ammer (1993), Fama and French (1993), Campbell, Sunderam, and Viceira (2013), Baele, Bekaert, and Inghelbrecht (2010), and Baker and Wurgler (2012)). The basic finding is that this relation varies over time. These and other authors focus on explanations that depend either on shocks to the real economy and inflation or on shocks to liquidity, uncertainty, or aggregate behavioral phenomena. However, none of these analyses build into their framework the fact that equity is generally short fixed rate debt. It is interesting to see how much of the time variation in stock and bond comovements can be explained by this fact alone.

\section{Figure 4}

This figure plots the market asset to book debt ratio (MABD) and correlations between the monthly returns on the S\&P 500 and five-year Treasury bonds, estimated either from rolling 36-month windows or from the dynamic conditional correlation (DCC) model. The MABD ratios are calculated as aggregate market equity plus book debt (long-term debt and debt in current liabilities) divided by aggregate book debt, using the firms in the S\&P 500 index. The DCC model is estimated from the following the mean-reverting model: $\rho_{t}=\alpha+\beta\left(\varepsilon_{\text {stock }, t-1} \varepsilon_{\text {bond }, t-1}-\alpha\right)+\gamma\left(\rho_{t-1}-\alpha\right)$, where $\varepsilon_{\text {stock }, t-1}$ and $\varepsilon_{b o n d, t-1}$ are standardized returns from the $\operatorname{GARCH}(1,1)$ model.

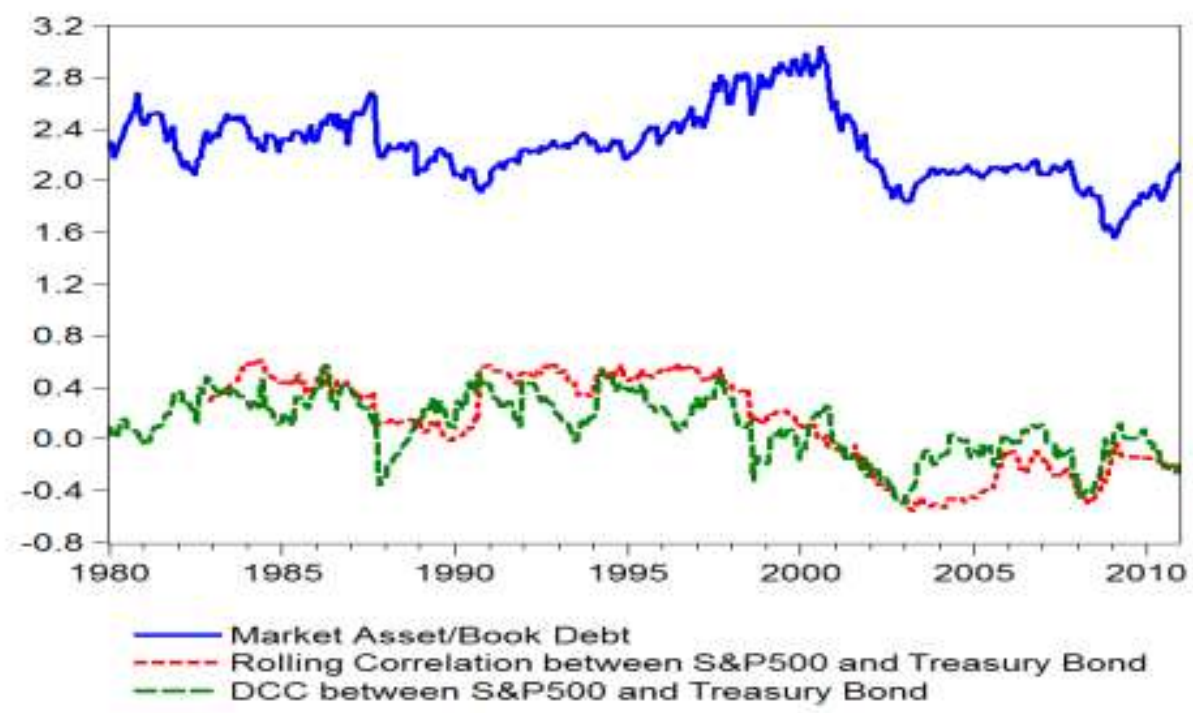


The theory of Section II and the empirical analysis of Section III show the importance of the relative value of the firm's assets to its debt obligations. Figure 4 above graphs the aggregate rolling estimate of this leverage measure and two measures of the correlation between the returns on equity and debt. The correlations are estimated using either a 36-month rolling window of monthly S\&P 500 returns and five-year Treasury returns or from a meanreverting DCC model. Consistent with earlier evidence and with the capital structure theory, Figure 4 shows that there appears to be a close relation between the comovements of stock and bond returns and the degree of leverage in the economy. In fact, the correlation is 0.63 between the inverse of aggregate leverage and the comovements of equity and government bond returns. This figure suggests that any theoretical model developed to explain the comovement of equity returns and interest rates should include the fact that equity is effectively short the corporate bond market. As a corollary to this point, empirical work documenting these comovements should include some measure of aggregate leverage within the economy. For example, Baele, Bekaert, and Inghelbrecht (2010) use a dynamic factor model to explore the determinants of the correlation between equity and bond returns. They use a variety of macroeconomic factors, including interest rates, inflation and the output gap amongst others, plus measures of changing risk aversion and proxies for liquidity. Their basic finding is that macroeconomic factors play little role in explaining equity and bond comovements and that "non-fundamental" factors like liquidity are more important.

We perform an analysis similar to that in Baele, Bekaert and Inghelbrecht (2010), but we include aggregate leverage as an additional factor. Specifically, we regress the 36-month rolling correlation between equity and bond returns on measures of market illiquidity, uncertainty, and risk premiums in addition to aggregate leverage. The stock market illiquidity measure is the market capitalization-weighted frequency of zero daily returns within a month across all firms while bond market illiquidity is measured by a monthly average of quoted bid-ask spreads. We also include the interaction between these two illiquidity measures to capture any comovement effects of market illiquidity. In addition to these illiquidity measures, we include VIX to measure market uncertainty, and the dividend yield, default spread, term spread, and T-bill rates in order to capture the effect of time-varying risk premiums on the bond-equity correlation as in Baele, Bekaert, and Inghelbrecht (2010). 
Lastly, we employ the ratio of the value of aggregate book debt to market assets as our measure of leverage. All the explanatory variables are standardized to allow easier comparisons of economic significance. The sample starts in 1990 due to the availability of VIX.

Table 7 reports the results. We find that aggregate leverage is negatively related to the bondequity correlation, which is consistent with Figure 4. The coefficient estimate on leverage is highly statistically and economically significant. For example, a one standard deviation increase in leverage decreases the bond-equity correlation by 0.11 when all the control variables including the market risk premium are present. The increase in $\mathrm{R}^{2}$ is also substantial, namely from $84.3 \%$ to $90.7 \%$ when leverage is added to the Baele, Bekaert, and Inghelbrecht (2010) factors for market liquidity and uncertainty. For robustness, we report the same regression results using firms from the CRSP/Compustat universe. We find similar results, although the economic significance is slightly lower. Overall the results indicate that financial leverage is an important variable for explaining the correlation between equity and bond returns.

As another example of the aforementioned literature, researchers have tried to relate stock and bond returns to aggregate bond factors unconditionally. For example, consider the popular Fama and French (1993) regression framework:

$$
R_{t, t+1}^{B_{i}}-R_{t}^{F}=\alpha+\beta_{1}\left(R_{t, t+1}^{L T G}-R_{t}^{F}\right)+\beta_{2}\left(R_{t, t+1}^{C O R P}-R_{t, t+1}^{L T G}\right)+\varepsilon_{t, t+1},
$$

where $R_{t, t+1}^{L T G}-R_{t}^{F}$ is the excess return on a long-term government bond (term factor) and $R_{t, t+1}^{C O R P}-R_{t, t+1}^{L T G}$ is the return on corporate debt minus the return on a long-term government bond (default factor). The purpose of this specification is to decompose return premiums into components due to the term premium (interest rate risk) and the default premium (default risk). Depending on the priority structure of the underlying corporate debt, equation (2) and Figure 2 show that this approach may be misleading. It is quite possible that $R_{t, t+1}^{C O R P}$ includes firms with debt of different priorities, which will affect the dependence of these debt returns on interest rates. If the sensitivity of $R_{t, t+1}^{C O R P}$ to interest rates differs from that of $R_{t, t+1}^{L T G}$, then the 
difference picks up both interest rate risk and default risk. In the extreme case where corporate debt is insensitive to interest rates, the coefficient on the term factor variable will equal the sum of the coefficients in the regression that correctly isolates default and term risk. In other words, because the mismeasured default factor loads negatively on the term factor, the coefficient on this latter factor needs to be higher in order to offset this effect, and the apparent effect of interest rate risk will be overstated.

To better understand the potential issue with the specification in equation (5), we run two sets of regressions of returns on different portfolios of bond and equities sorted by their firm ratings (i.e., AAA, AA, A, BBB, BB and B) against the five Fama and French (1993) factors (i.e., equity (market, SMB, and HML) and bond (TERM and DEF)). The sets of regressions differ by their definition of DEF, one using Fama and French's (1993) definition in equation (5) above, and the other recognizing that the duration of corporate bonds differs from that of government bonds. In particular, denote the return spread between aggregate corporate bonds and long-term government bonds similar to Fama and French (1993) as DEF1. The return spread that considers the duration of corporate bonds is denoted as DEF2, which is the difference between returns on aggregate corporate bonds and a short-term government bond (five-year maturity). The sample period is from 1990 to 2007 because of the availability of returns on high-yield bond indices.

Table 8, Panels A and B provide the regression results for equation (5) for six issuer-level ratings portfolios, using the two default factors, DEF1 and DEF2. Since corporate bonds have a much shorter duration than long-term Treasury bonds, DEF1 captures not only the default component of equity and bond returns, but also the negative of the term factor (TERM). Thus, there will be an upward bias in the coefficient on TERM and possibly also a bias in the coefficient on DEF1. In contrast, DEF2 is a cleaner measure of the default factor than DEF1, and the coefficients in this regression should present a more accurate picture of loadings on default and interest rate risk.

For both equity and bond portfolio returns, the loadings on TERM tend to be larger in Panel A, especially among bond portfolios. For example, the coefficients in Panel A for the BB and 
$\mathrm{B}$ bonds are 1.01 and 1.58, versus 0.21 and 0.15 in Panel B. Thus, it is clear that the misspecified regression vastly overstates the effect of interest rate risk on return premiums for high-yield bonds. For high grade bond returns, the loadings on DEF1 are significantly larger than those on DEF2 $(0.27,0.36$, and 0.49 versus $0.04,0.05$ and 0.21 , for the AAA, AA and A indexes), indicating that the typical approach, following Fama and French (1993), erroneously exaggerates the perceived degree of default risk among investment grade bonds.

\section{B. Time-Variation in Expected Returns}

In his recent AFA presidential address, Cochrane (2013) states that discount rate variation is the central question of asset pricing research. He argues that understanding the multivariate factor structure of expected returns on different asset classes, such as stocks and bonds, is key. He then goes on to describe various candidate models from macroeconomics and those based on standard finance theory, market frictions and behavioral economics. However, he does not discuss the potential importance of leverage and the structural link between stocks and bonds described in this paper. In fact, Cochrane (2013) frames his question by writing a joint expression for stock and bond returns as

$$
\begin{aligned}
& R_{E: t, t+1}=\alpha_{E}+\beta_{1 e} d p_{t}+\beta_{2 e} y s_{t}+\beta_{z e}^{\prime} z_{t}+\varepsilon_{E: t, t+1} \\
& R_{B: t, t+1}=\alpha_{B}+\beta_{1 b} d p_{t}+\beta_{2 b} y s_{t}+\beta_{z b}^{\prime} z_{t}+\varepsilon_{B: t, t+1}
\end{aligned}
$$

where $R_{E: t, t+1}$ is the return on stocks, $R_{B: t, t+1}$ is the return on bonds, $d p_{t}$ is the dividend yield on stocks (or more broadly equity-like factors), $y s_{t}$ is the term spread on bonds (or more broadly bond-like factors), and $z_{t}$ are additional predictor variables. He suggests that the finance field needs to better understand the coefficients $\beta_{2 e}, \beta_{z e}, \beta_{1 b}$, and $\beta_{z b}$.

There has been a growing literature in finance over the last quarter century organized around identifying these coefficients. Examples of this literature include Keim and Stambaugh (1986), Campbell (1987), Fama and Bliss (1987), Fama and French (1989), Ferson and

Harvey (1991), Ilmanen (1995), Boudoukh, Richardson, and Whitelaw (1997), Campbell (2000), Harvey (2001), Lettau and Ludvigson (2001), Cochrane and Piazzesi (2005), Guo and Whitelaw (2006), Ang and Bekaert (2007), Boudoukh, Michaely, Richardson, and Roberts (2007), Bollerslev, Tauchen, and Zhou (2009) and Ludvigson and Ng (2009), 
among others. That said, while these papers identify the likely predictive variables, Cochrane (2013) correctly points out that there has not been much progress in understanding the joint determinants of time-varying expected returns on stocks and bonds. To the extent that these discount rates for stocks and bonds are determined by a single stochastic discount factor, there would be considerable benefit in advancing the literature in this direction.

However, it is clear from Cochrane's discussion and, for that matter, much of the aforementioned literature that researchers consider a portfolio of firm equity returns and a portfolio of firm asset returns as interchangeable. Of course, this treatment ignores the levered nature of equity returns, namely that stock returns are long asset returns and short bond returns. In other words, equation (6) should ideally be represented in the following form:

$$
\begin{aligned}
\frac{A_{t}}{E_{T}} R_{A: t, t+1}-\frac{D_{t}}{E_{t}} R_{B: t, t+1} & =\alpha_{E}+\beta_{1 e} d p_{t}+\beta_{2 e} y s_{t}+\beta_{z e}^{\prime} z_{t}+\varepsilon_{E: t, t+1} \\
R_{B: t, t+1} & =\alpha_{B}+\beta_{1 b} d p_{t}+\beta_{2 b} y s_{t}+\beta_{z b}^{\prime} z_{t}+\varepsilon_{B: t, t+1}
\end{aligned}
$$

Table 9 documents results from the estimation of regression system (6), plus an additional regression with asset returns, using the following three predictors: (i) the dividend yield, $d p_{t}$, of Fama and French (1988), (ii) the term spread, $y s_{t}$, i.e., the difference between the 10-year, constant maturity Treasury yield and the 3-month T-bill rate, and (iii) the yield spread between high yield corporate bonds and T-bills, denoted $z_{t} \equiv d e f_{t}$. We run the regressions using the firms in the sample underlying the results reported in Table 8.

The economic magnitudes of the coefficients in Table 9 highlight the intuition outlined above, although some of the coefficient estimates are statistically insignificant due to our relatively short sample period from 1991 to 2007 . The predictability of the dividend yield is strong for equity returns. This result largely stems from asset returns, i.e., asset returns also exhibit strong predictability. In contrast, the dividend yield predicts bond returns only weakly. Similarly, the negative coefficient on the term spread for equity returns, albeit statistically insignificant, comes mainly from the levered position in asset returns (i.e., $\frac{A}{E} R_{A: t, t+1}$ ). In both cases, the coefficient on equity returns is between 20 and $30 \%$ larger than the corresponding 
coefficient in the asset return equation, consistent with the degree of leverage in the sample and the weak link between the predictor and bond returns.

On the other hand, the estimated coefficient on the default spread is due, at least in part, to the short position in bond returns. Corporate bond returns load positively and with borderline statistical significance on this spread, which is not surprising. Consequently, since equity holders are effectively short this bond return, the negative coefficient on this spread in the equity equation reflects this short position.

Thus, the above analysis shows that an understanding of the discount factors for stocks and bonds, i.e., the coefficients in equations (6) and (7), is only possible when one recognizes that equity is a long position in the assets of the firm with a short position in fixed-rate debt.

Even if the researcher uses this insight, there is still the question of how to choose and interpret the predictive variables. For example, in Table 9 we used two common predictive variables, namely the term premium - the yield spread between long-term government and short-term government bonds - and the default premium - the yield spread between highyield corporate debt and T-bills (see, for example, Keim and Stambaugh (1986)). Fama and French (1989) argue that the appropriate default premium should be the yield spread between high-yield corporate debt and AAA-rated corporate debt, presumably to isolate the default risk from the interest rate risk. However, as pointed out in Section IV.A, changes in yields of low priority corporate debt have little relation to changes in interest rates. Therefore, the default premium may in fact be comingling the two risk components. A comparison of the two seminal papers in the area - Keim and Stambaugh (1986) and Fama and French (1993) shows different results. This is likely due to different definitions of the default premium. The former paper uses short-term bond yields while the latter uses long-term bond yields as the benchmark for the default premium.

Table 10 reports results using these two different measures and shows, in fact, that there is a significant difference in the economic magnitudes of the coefficients. We use $\operatorname{def}(\mathrm{KS})$, the yield difference between high yield bonds and 3-month T-bills, and $\operatorname{def}(\mathrm{FF})$, the yield 
difference between high yield and AAA-rated corporate bonds. Interpreted in the context of our results above, $\operatorname{def}(\mathrm{KS})$ captures time-varying expected returns driven mainly by the default risk of bonds, whereas $\operatorname{def}(\mathrm{FF})$ is a mixed measure that captures both the default and term premium components. The empirical results are consistent with this intuition. In the regression using the Keim-Stambaugh style variable, $\operatorname{def}(\mathrm{KS})$, the coefficient estimates are -0.14 and -0.20 for the yield spread and default spread, respectively. However, in the regression using $\operatorname{def}(\mathrm{FF})$, we find that both the estimates are further away from zero, taking on the values -0.36 and -0.28 for the yield spread and default spread, respectively. Thus, this latter regression may erroneously suggest larger term and default risk premiums than actually exist. Again, while the individual coefficient estimates are not statistically significant due to our relatively short sample, the differences are both economically and statistically significant (at least for default spread), and these differences illustrate the need to be careful when analyzing aggregate equity and bond returns.

\section{Asset Returns and Inflation}

A well known result in the finance literature is that ex post (realized) nominal stock returns and inflation are negatively correlated (e.g., Fama and Schwert (1977) and Boudoukh and Richardson (1994)). This result is somewhat surprising since stocks, as claims against real assets, should compensate for movements in inflation. Of course, the theory and evidence in Sections II and III, respectively, make the point that while stocks are claims on real assets, they are also short debt, i.e., short the default-free value of the firm's debt albeit with a put option on the real assets.

In fact, the typical regression of stock returns on contemporaneous inflation can be broken down as follows:

$$
R_{t, t+1}^{E} \equiv R_{t, t+1}^{V}+\frac{D_{t}}{E_{t}}\left(R_{t, t+1}^{V}-R_{t, t+1}^{D}\right)=\alpha+\beta \pi_{t, t+1}+\varepsilon_{t, t+1}
$$

where $R_{t, t+1}^{E}$ is the one-period return on the equity of a firm, $R_{t, t+1}^{V}$ is the one-period return on the firm's assets, $R_{t, t+1}^{D}$ is the one-period return on the firm's debt, $\pi_{t, t+1}$ is the one-period inflation rate, $E_{t}$ is the market value of the firm's equity, $V_{t}$ is the market value of the firm's 
assets, and $D_{t}$ is the market value of the firm's debt. $R_{t, t+1}^{V}$ and $\pi_{t, t+1}$ might be expected to move one-for-one (i.e., $\beta=1$ ), but this is not necessarily true for $\frac{D_{t}}{E_{t}}\left(R_{t, t+1}^{V}-R_{t, t+1}^{D}\right)$. In particular, while the effect of expected inflation on the asset and debt returns may offset each other under the Fisher effect, the returns will move in opposite directions with respect to unexpected inflation as the fixed debt claim loses (gains) value while the value of the firm, as a claim on real assets, increases (decreases) for a positive (negative) shock to inflation. Of course, this effect only serves to compound the puzzle that the estimated coefficient in equation (8) is negative, as it will cause $\beta>1$.

In order to better understand the implications of equation (8), Table 11 investigates empirically the relation between inflation and the two components of equity returns, $R_{t, t+1}^{V}$ and $\frac{D_{t}}{E_{t}}\left(R_{t, t+1}^{V}-R_{t, t+1}^{D}\right)$, as well as $R_{t, t+1}^{E}$. Table 11 provides estimates from time-series regressions with and without proxies for real variables. Fama (1981) and others have argued that the Fisher effect does not appear to hold empirically because inflation proxies for future economic activity. Once this proxy effect is accounted for, the anomalous negative relation between equity returns and inflation disappears. Like Fama (1981), we use ex post proxies for real activity.

Table 11 duplicates the anomalous result that stock returns do not move one-for-one with inflation. Using quarterly data, the coefficient on inflation is similar for the equity and asset return regressions, taking on values of 0.33 and 0.28 , respectively, implying that the remainder term $\frac{D_{t}}{E_{t}}\left(R_{t, t+1}^{V}-R_{t, t+1}^{D}\right)$ has a coefficient close to zero. Our failure to duplicate the negative coefficient found in much of the literature is presumably due to our sample period.

Of particular interest, when the proxy variables are included, the coefficient on inflation increases up to values of 1.46 and 1.14 for equity and asset returns, respectively. The Fisher effect implies 1.0 for the assets, and, in contrast to the existing literature, a value greater than 
1.0 for equity due to equity being short fixed rate debt. While the individual coefficients have relatively high standard errors, the difference is statistically and economically significant, consistent with the theory.

\section{The Betas of Corporate Bonds}

There is an extensive literature in finance that tries to measure the beta of corporate bond returns. Using a standard market model motivated by the CAPM, Alexander (1980) and Chang and Huang (1990), among others, have run typical regressions of excess corporate bond returns on aggregate equity market returns and found the betas to be quite low. Alternatively, using Merton (1974) as motivation, a number of authors have run similar regressions on excess long-term government bond returns and the spread between investment-grade corporate bond and long-term government bond returns. Depending on the formulation, the success of these models is mixed (see, for example, Fama and French (1993), Elton, Gruber, Agrawal, and Mann (2001), Gebhardt, Hvidkjaer, and Swaminathan (2005), and Bao, Pan, and Wang (2011)).

Consider first the CAPM regression. Once one recognizes the priority tranches of each firm, it is not surprising that the typical CAPM regression produces counter-intuitive results. Rewriting the aggregate market return in terms of the underlying assets and debt,

$$
\begin{aligned}
R_{t, t+1}^{B_{i}}-R_{t}^{F} & =\alpha+\beta\left(R_{t, t+1}^{M}-R_{t}^{F}\right)+\varepsilon_{t, t+1} \\
& =\alpha+\beta\left(\left(R_{t, t+1}^{V_{M}}-R_{t}^{F}\right)+\frac{D_{M t}}{E_{t}}\left(R_{t, t+1}^{V_{M}}-R_{t, t+1}^{D_{M}}\right)\right)+\varepsilon_{t, t+1}
\end{aligned}
$$

the corporate bond's beta includes two terms, $\operatorname{cov}\left(R_{t, t+1}^{B_{i}}, R_{t, t+1}^{V_{M}}\right)$ and $\operatorname{cov}\left(R_{t, t+1}^{B_{i}}, \frac{D_{M t}}{E_{t}}\left(R_{t, t+1}^{V_{M}}-R_{t, t+1}^{D_{M}}\right)\right)$. The first term is the covariance of a firm's bond return of a particular priority (or of a portfolio of bond returns) with the aggregate return on the assets of all firms. This is what we would normally consider to be the typical CAPM framework. If a firm's debt value (i.e., default probability) does not vary much with the aggregate economy, then the beta would typically be close to zero. This is not necessarily true in equation (9). To the extent that aggregate corporate debt in the economy moves with interest rates, the estimated beta from equation (9) for relatively safe firm debt will tend to be negative as 
$\operatorname{cov}\left(R_{t, t+1}^{B_{i}}, \frac{D_{M t}}{E_{t}}\left(R_{t, t+1}^{V_{M}}-R_{t, t+1}^{D_{M}}\right)\right)<0$. Alternatively, if a firm's debt value does vary greatly with the aggregate economy, yet does not vary much with interest rates (due to the priority of its claim), then the estimated beta from equation (9) will be positive yet scaled down by $\frac{V_{M t}}{E_{t}}$. That said, it should be clear that the $\beta$ estimate will depend mostly on the priority of the bond for the firm in question. Equation (9) also makes obvious the fact that these relations are time-varying if for no other reason than their dependence on $\frac{V_{M t}}{E_{t}}$, which varies through time.

Table 12 reports results for the typical CAPM regression for corporate bonds using the aggregate market return. We perform these regressions for portfolios of bonds with different maturities, different capital structure priorities, and different levels of credit risk. Consistent with existing evidence, all the coefficients on investment grade bonds are small and close to zero. This result implies that investment grade corporate bond returns have low risk premiums, giving credence to the fact that the yield spreads on corporate bonds seem too high given their low default probability. The coefficients on high yield bonds are higher, but arguably lower than one might expect given the close relation between low priority, risky debt and equity.

However, the discussion above suggests that the use of the aggregate equity return in the CAPM regression might be misleading given the fact that equity claims are long the assets and short fixed rate debt. We rerun regression equation (9) in two different ways. First, we separate the aggregate equity return into the asset return and a remainder term which captures the short debt component. Second, we use the return on aggregate assets as the factor.

With respect to the former, the results are startling. The beta coefficient on the asset return is considerably higher while the coefficient on the remainder term is negative. For example, consider the medium-term maturity (5-8 and 8-15 years), high priority, investment grade portfolios. The beta coefficients go from 0.09 and 0.14 to 0.58 and 0.79 , respectively when we break equity into its relevant components. The remainder term has a coefficient of -1.68 
and -2.25 . Thus, the low beta of corporate bonds is not because the "true" asset beta is low but because its positive risk premium is offset by its short position in the bond market.

With respect to the latter, we document the betas of the various bonds against the aggregate return on assets. The results are less dramatic but still point in the same direction. For all bonds, irrespective of maturity, priority, or credit risk, the beta is higher using asset returns than market returns. For example, consider the medium-term maturity (5-8 and 8-15 years), high priority, investment grade portfolios. The beta coefficients go from 0.09 and 0.14 to 0.13 and 0.20 , respectively. Both this result and the one above provide some evidence that corporate bonds are riskier than existing results might suggest.

\section{Concluding Remarks}

The basic message of this paper is that capital structure priority matters. Specifically, we appeal to contingent claim asset pricing to exploit capital structure priority to better understand the relation between security returns and interest rate changes (i.e., duration). In particular, we show theoretically and, using a novel dataset, confirm empirically that lower priority securities in the capital structure, such as subordinated or distressed debt and equity, have low or even negative duration. This result obtains because the lower priority securities are effectively short higher priority fixed rate debt, i.e., short the bond market.

Using these results, we investigate and reinterpret existing results in the literature that focus on aggregate phenomena such as (i) time-varying correlations between the aggregate stock market and government bonds, (ii) the Fisher effect and inflation, (iii) the beta of corporate bonds, and (iv) the use of bond factors in multifactor asset pricing models and for forecasting bond and stock returns. The bottom line from our analysis is that researchers need to rethink the way they use aggregate stock and bond data in light of the priority structure of firms. 


\section{References}

Acharya, Viral and Jennifer Carpenter, 2002, Corporate Bond Valuation and Hedging with Stochastic Interest Rates and Endogenous Bankruptcy, Review of Financial Studies 15, 13551383.

Acharya, Viral, Iftekhar Hasan and Anthony Saunders, 2006, Should Banks Be Diversified? Evidence from Individual Bank Loan Portfolios, Journal of Business 79, 1355-1412.

Alexander, Gordon, 1980, Applying the Market Model to Long-term Corporate Bonds, Journal of Financial and Quantitative Analysis 15, 1063-1080.

Altman, Edward and William Stonberg, 2006, The Market in Defaulted Bonds and Bank Loans, Journal of Portfolio Management 32, 93-105.

Ang, Andrew and Geert Bekaert, 2007, Stock Return Predictability: Is It There? Review of Financial Studies 20, 651-707.

Bao, Jack, Jun Pan and Jiang Wang, 2011, The Illiquidity of Corporate Bonds, Journal of Finance 66, 911-946.

Barsky, Robert B., 1989, Why Don't the Prices of Stocks and Bonds Move Together? American Economic Review 79, 1132-1145.

Baele, Lieven, Geert Bekaert and Koen Inghelbrecht, 2010, The Determinants of Stock and Bond Comovements, Review of Financial Studies 23, 2374-2428.

Baker, Malcolm and Jeffrey Wurgler, 2012, Comovement and Predictability Relationships between Bonds and the Cross-Section of Stocks, Review of Asset Pricing Studies 2, 57-87.

Bekaert, Geert and Eric Engstrom, 2010, Inflation and the Stock Market: Understanding the "Fed Model", Journal of Monetary Economics 57, 278-294.

Bekaert, Geert, Eric Engstrom and Steven Grenadier, 2010, Stock and Bond Returns with Moody Investors, Journal of Empirical Finance 17, 867-894.

Bekaert, Geert, Campbell R. Harvey and Christian Lundblad, 2007, Liquidity and Expected Returns: Lessons from Emerging Markets, Review of Financial Studies 20, 1783-1831.

Bharath, Shreedhar and Tyler Shumway, 2008, Forecasting Default with the Merton Distance to Default Model, Review of Financial Studies 21, 1339-1369.

Blume, Marshall, Donald Keim and Sandeep Patel, 1991, Returns and Volatility of LowGrade Bonds: 1977-1989, Journal of Finance 46, 49-74.

Bollerslev, Tim, George Tauchen and Hao Zhou, 2009, Expected Stock Returns and Variance Risk Premia, Review of Financial Studies 22, 4463-4492. 
Boudoukh, Jacob and Matthew Richardson, 1993, Stock Returns and Inflation: A LongHorizon Perspective, American Economic Review 83, 1346-1355.

Boudoukh, Jacob, Roni Michaely, Matthew Richardson and Michael R. Roberts, 2007, On the Importance of Measuring Payout Yield: Implications for Empirical Asset Pricing, Journal of Finance 62, 877-915.

Boudoukh, Jacob, Matthew Richardson and Robert F. Whitelaw, 1994, Industry Returns and the Fisher Effect, Journal of Finance 49, 1595-1615.

Boudoukh, Jacob, Matthew Richardson and Robert F. Whitelaw, 1997, Nonlinearities in the Relation Between the Equity Risk Premium and the Term Structure, Management Science 43, 371-385.

Campbell, John Y., 1987, Stock Returns and the Term Structure, Journal of Financial Economics 18, 373-399.

Campbell, John Y. and John Ammer, 1993, What Moves the Stock and Bond Markets? A Variance Decomposition for Long-Term Asset Returns, Journal of Finance 48, 3-37.

Campbell, John Y. and John H. Cochrane, 1999, By Force of Habit: A Consumption-Based Explanation of Aggregate Stock Market Behavior, Journal of Political Economy 107, 205251.

Campbell, John Y., 2000, Asset Pricing at the Millennium, Journal of Finance 55, 15151567.

Campbell, John Y., Adi Sunderam and Luis M. Viceira, 2013, Inflation Bets or Deflation Hedges? The Changing Risks of Nominal Bonds, Harvard University working paper.

Chance, Don, 1990, Default Risk and the Duration of Zero Coupon Bonds, Journal of Finance 46, 265-274.

Chang, Eric and Roger Huang, 1990, Time-Varying Return and Risk in the Corporate Bond Market, Journal of Financial and Quantitative Analysis 25, 323-340.

Choi, Jaewon, 2013, What Drives the Value Premium? The Role of Asset Risk and Leverage, Review of Financial Studies 26, 2845-2875.

Cochrane, John H., 2011, Presidential Address: Discount Rates, Journal of Finance 66, 1047-1108.

Cochrane, John H. and Monika Piazzesi, 2005, Bond Risk Premia, American Economic Review 95, 138-160. 
Collin-Dufresne, Pierre, Robert S. Goldstein and J. Spencer Martin, 2001, The Determinants of Credit Spread Changes, Journal of Finance 56, 2177-2207.

Connolly, Robert, Chris Stivers and Licheng Sun, 2005, Stock Market Uncertainty and the Stock-Bond Return Relation, Journal of Financial and Quantitative Analysis 40, 161-194.

Elton, Edwin J., Martin J. Gruber, Deepak Agrawal and Christopher Mann, 2001. Explaining the Rate Spread on Corporate Bonds, Journal of Finance 56, 247-277.

Eom, Young H., Jean Helwege and Jing-Zhi Huang, 2004, Structural Models of Corporate Bond Pricing: An Empirical Analysis, Review of Financial Studies 17, 499-544.

Ericsson, Jan, Kris Jacobs and Rodolfo Oviedo, 2009, The Determinants of Credit Default Swap Premia, Journal of Financial and Quantitative Analysis 44, 109-132.

Fama, Eugene F. and Robert R. Bliss, 1987, The Information in Long-Maturity Forward Rates, American Economic Review 77, 680-92.

Fama, Eugene F. and William G. Schwert, 1977, Asset Returns and Inflation, Journal of Financial Economics 5, 115-146.

Fama, Eugene F., 1981, Stock Returns, Real Activity, Inflation, and Money, American Economic Review 71, 545-565.

Fama, Eugene F. and Kenneth R. French, 1988, Dividend Yields and Expected Stock Returns, Journal of Financial Economics 22, 3-25.

Fama, Eugene F. and Kenneth R. French, 1989, Business conditions and expected returns on stocks and bonds, Journal of Financial Economics 25, 23-49.

Fama, Eugene F. and Kenneth R. French, 1993, Common Risk Factors in the Returns on Stocks and Bonds, Journal of Financial Economics 33, 3-56.

Ferson, Wayne E. and Campbell R. Harvey, 1991, The Variation of Economic Risk Premiums, Journal of Political Economy 99, 385-415.

Gebhardt, William, Soeren Hvidkjaer and Bhaskaran Swaminathan, 2005, The Cross-Section of Expected Corporate Bond Returns: Betas or Characteristics, Journal of Financial Economics 75, 85-114.

Guo, Hui and Robert F. Whitelaw, 2006, Uncovering the Risk-Return Relation in the Stock Market, Journal of Finance 61, 1433-1463.

Harvey, Campbell R., 2001, The Specification of Conditional Expectations, Journal of Empirical Finance 8, 573-637. 
Ilmanen, Antti, 1995, Time-Varying Expected Returns in International Bond Markets, Journal of Finance 50, 481-506.

Jones, Philip E., Scott P. Mason and Eric Rosenfeld, 1984, Contingent Claims Analysis of Corporate Capital Structures: An Empirical Investigation, Journal of Finance 39, 1-25.

Keim, Donald B. and Robert F. Stambaugh, 1986, Predicting Returns in the Stock and Bond Markets, Journal of Financial Economics 17, 357-390.

Koijen, Ralph, Hanno Lustig and Stijn Van Nieuwerburgh, 2012, The Cross-Section and Time-Series of Stock and Bond Returns, New York University working paper.

Lettau, Martin and Sydney C. Ludvigson, 2001, Consumption, Aggregate Wealth and Expected Stock Returns, Journal of Finance 56, 815-849.

Ludvigson, Sydney C. and Serena Ng, 2009, Macro Factors in Bond Risk Premia, Review of Financial Studies 22, 5027-5067.

Merton, Robert. C., 1973, Theory of Rational Option Pricing, Bell Journal of Economics and Management Science 4, 141-183

Merton, Robert. C., 1974, On the Pricing of Corporate Debt: The Risk Structure of Interest Rates, Journal of Finance 29, 449-70.

Modigliani, Franco and Merton Miller, 1958, The Cost of Capital, Corporation Finance and the Theory of Investment, American Economic Review 48, 261-297.

Rabinovitch, Ramon, 1989, Pricing Stock and Bond Options when the Default-Free Rate is Stochastic, Journal of Financial and Quantitative Analysis 24, 447-457

Schaefer, Stephen and Ilya Strebulaev, 2008, Structural Models of Credit Risk Are Useful: Evidence from Hedge Ratios on Corporate Bonds, Journal of Financial Economics 90, 1-19.

Shiller, Robert J. and Andrea E. Beltratti, 1992, Stock Prices and Bond Yields: Can Their Comovements be Explained in Terms of Present Value Models? Journal of Monetary Economics 30, 25-46.

Taylor, Allison and Alicia Sansone, 2007, The Handbook of Loan Syndications and Trading. McGraw-Hill, New York.

Vasicek, Oldrich, 1977, An Equilibrium Characterization of the Term Structure, Journal of Financial Economics 5, 177-188. 


\section{Table 1: Summary Statistics}

The sample includes firms with asset return data available for the period from 1980 to 2007, excluding financial firms. Panel A provides the fraction of book debt (long-term debt plus debt in current liabilities) that is covered by bonds and loans found in the FISD and Dealscan databases. Panel B reports the fraction of bonds out of total assets across priority groups. We categorize each firm-month observation into one of four priority groups based on the number of different bond priority levels within the capital structure of the firm. For each priority group, we report average time-to-maturity and the fraction of high and low priority bonds out of total assets, separately for fixed and floating rate bonds. For firms with an odd numbers of priority levels $(2 n-1)$, the bonds in the higher $n$ priority levels are defined as high priority and the bonds in the lower $(n-1)$ priority levels are defined as low priority. For firms with even numbers or priority levels $(2 n)$, the bonds in the higher $n$ priority levels are defined as high priority and the bonds in the lower $n$ priority levels as low priority. In Panel C, we report the average and the $25^{\text {th }}, 50^{\text {th }}$, and $75^{\text {th }}$ percentiles of market assets $(M A)$, market debt to market equity $(M D / M E)$, and market assets to book debt $(M A / B D)$.

Panel A: Debt Coverage

\begin{tabular}{ccccc}
\hline \multicolumn{2}{c}{ Equally Weighted } & & \multicolumn{2}{c}{ Value Weighted } \\
\cline { 1 - 1 } \cline { 5 - 6 } Bonds & Bonds+Loans & & Bonds & Bonds+Loans \\
$65.2 \%$ & $96.2 \%$ & & $59.8 \%$ & $89.6 \%$ \\
\hline
\end{tabular}

Panel B: Debt Priority Distribution

\begin{tabular}{|c|c|c|c|c|c|c|c|}
\hline & & $\begin{array}{c}\text { \# of Priority } \\
\text { \# of Obs. }\end{array}$ & $\begin{array}{c}1 \\
166,207 \\
\end{array}$ & $\begin{array}{c}2 \\
43,785\end{array}$ & $\begin{array}{c}3 \\
14,532 \\
\end{array}$ & $\begin{array}{c}4 \text { or more } \\
10,811\end{array}$ & $\begin{array}{c}\text { Total } \\
235,335\end{array}$ \\
\hline \multirow{7}{*}{ Priority } & \multirow{3}{*}{ High } & Fixed & $30.1 \%$ & $18.6 \%$ & $31.4 \%$ & $22.0 \%$ & \\
\hline & & Floating & $0.6 \%$ & $0.7 \%$ & $0.8 \%$ & $1.3 \%$ & \\
\hline & & Avg. Maturity & 5.49 & 5.69 & 5.88 & 6.50 & \\
\hline & \multirow{4}{*}{ Low } & Fixed & & $14.0 \%$ & $20.2 \%$ & $12.8 \%$ & \\
\hline & & Floating & & $0.6 \%$ & $0.3 \%$ & $0.6 \%$ & \\
\hline & & Avg. Maturity & & 5.90 & 5.70 & 6.04 & \\
\hline & & Loan & $15.9 \%$ & $13.3 \%$ & $14.6 \%$ & $16.7 \%$ & \\
\hline
\end{tabular}

Panel C: Leverage Distribution

\begin{tabular}{ccccc}
\hline & Avg. & $25^{\text {th }}$ Pct. & $50^{\text {th }}$ Pct. & $75^{\text {th }}$ Pct. \\
\hline MA & 7422.6 & 714.4 & 1940.7 & 5437.3 \\
MD/ME & 0.75 & 0.08 & 0.32 & 0.78 \\
MA/BD & 5.02 & 1.25 & 2.42 & 4.70 \\
\hline
\end{tabular}




\section{Table 2: Simple Duration Estimates}

This table reports the modified duration of different classes of securities for the period from 1980 to 2007. We estimate the duration, $\beta$, from the following pooled regression for firms in five different groups sorted on leverage:

$$
R_{t}^{i}=\alpha+\beta\left(-\Delta i_{t}\right)+\varepsilon_{t}
$$

where $R_{t}^{i}$ is the return on junior or senior bond, equity, or assets and $i_{t}$ is the five-year, constant maturity Treasury yield. The senior and junior bond returns are obtained by value-weighting high and low priority bonds for each firm, respectively. The high and low priority bonds are defined as in Table 1. Firms are sorted each year into a zero leverage group and four other groups of equal size based on the market assets to book debt ratio from the previous year. To be included in these four, leverage-sorted groups, firms are required to have both high and low priority bonds with time-to-maturity longer than three years and bond amounts greater than 10\% of the issuing firms' total debt. The reported duration estimates are the OLS estimates from pooled regressions for each leverage group. *, **, and *** denote statistical significance at the 10,5 , and $1 \%$ levels. Numbers in parentheses are White robust standard errors.

\begin{tabular}{cccccc}
\hline $\begin{array}{c}\text { Leverage } \\
\text { Quintile }\end{array}$ & & Senior & Junior & Equity & Asset \\
\hline Zero & Avg. Ret & & & $1.89 \%$ & $1.89 \%$ \\
& Stdev. Ret & & & $21.08 \%$ & $21.07 \%$ \\
& $\beta$ & & & -0.26 & -0.26 \\
& & & & $(0.18)$ & $(0.18)$ \\
& $R^{2}$ & & & $0.0 \%$ & $0.1 \%$ \\
\hline 1 & Avg. Ret & $0.60 \%$ & $0.51 \%$ & $0.76 \%$ & $0.72 \%$ \\
& Stdev. Ret & $3.28 \%$ & $5.28 \%$ & $10.47 \%$ & $9.45 \%$ \\
& $\beta$ & $3.18 * * *$ & $2.45 * * *$ & -0.46 & -0.17 \\
& & $(0.14)$ & $(0.24)$ & $(0.48)$ & $(0.43)$ \\
& $R^{2}$ & $7.8 \%$ & $1.8 \%$ & $0.0 \%$ & $0.0 \%$ \\
\hline 2 & Avg. Ret & $0.70 \%$ & $0.73 \%$ & $1.17 \%$ & $1.02 \%$ \\
& Stdev. Ret & $3.10 \%$ & $4.35 \%$ & $10.09 \%$ & $7.76 \%$ \\
& $\beta$ & $3.04 * * *$ & $2.62 * * *$ & 0.04 & $0.51 *$ \\
& & $(0.11)$ & $(0.16)$ & $(0.37)$ & $(0.29)$ \\
& $R^{2}$ & $8.8 \%$ & $3.3 \%$ & $0.0 \%$ & $0.0 \%$ \\
\hline 3 & Avg. Ret & $0.62 \%$ & $0.68 \%$ & $1.15 \%$ & $0.87 \%$ \\
& Stdev. Ret & $3.08 \%$ & $3.89 \%$ & $10.93 \%$ & $6.62 \%$ \\
& $\beta$ & $2.79 * * *$ & $2.41 * * *$ & 0.04 & 0.83 \\
& & $(0.11)$ & $(0.14)$ & $(0.40)$ & $(0.24)$ \\
& $R^{2}$ & $6.4 \%$ & $3.0 \%$ & $0.0 \%$ & $0.1 \%$ \\
\hline High & Avg. Ret & $0.79 \%$ & $0.78 \%$ & $1.27 \%$ & $0.88 \%$ \\
& Stdev. Ret & $4.07 \%$ & $6.22 \%$ & $15.33 \%$ & $6.19 \%$ \\
& $\beta$ & $2.22^{* * *}$ & $1.81 \% * *$ & 0.29 & $0.87^{* * *}$ \\
& & $(0.15)$ & $(0.22)$ & $(0.56)$ & $(0.23)$ \\
& $R^{2}$ & $2.5 \%$ & $0.7 \%$ & $0.0 \%$ & $0.2 \%$ \\
\hline
\end{tabular}




\section{Table 3: Duration of Bonds, Equity and Assets: Firm-Level Analysis}

This table reports the interest rate sensitivity of debt, equity, and assets for the period from 1980 to 2007 . We regress bond, equity and asset returns using the following pooled regression model:

$$
\begin{aligned}
& R_{t}=\alpha+\beta_{t} \tau_{t}\left(-\Delta i_{t}\right)+\theta_{t} R A_{t}+\varepsilon_{t} \\
& \beta_{t}=\beta_{0}+\beta_{1} L_{t}+\beta_{2} P_{t}+\beta_{3} L_{t} P_{t}+\beta_{4} Z_{t} \\
& \theta_{t}=\theta_{0}+\theta_{1} L_{t}+\theta_{2} P_{t}
\end{aligned}
$$

where $R_{t}$ is bond, equity, or asset return; $\tau_{t}$ is the time-to-maturity of the bond (for equity and asset, the timeto-maturity is set to one); $L_{t}$ is $\log$ book debt divided by market assets $\left(L_{t}=\log \frac{\Sigma K_{i}}{V_{t}}\right) ; P_{t}$ is priority of a bond defined as one minus the fraction of bonds in terms of face value that are senior to that bond; $Z_{t}$ is a set of dummy variables for callable, convertible, putable, floating rate and asset-backed bonds; $R A_{t}$ is asset return; and $\Delta i$ is the change in the five-year, constant maturity Treasury yield. We report pooled OLS estimation results with White robust standard errors (in parentheses). *,**, and *** denote statistical significance at the 10 ,

\begin{tabular}{|c|c|c|c|c|c|c|c|}
\hline \multirow[b]{2}{*}{ Intercept } & \multicolumn{3}{|c|}{ Bond } & \multicolumn{2}{|c|}{ Equity } & \multicolumn{2}{|c|}{ Asset } \\
\hline & $0.01^{* * *}$ & $0.01^{* * *}$ & $0.00^{* * * *}$ & $0.01^{* * *}$ & $0.00^{* * * *}$ & $0.01^{* * *}$ & $0.01^{* * *}$ \\
\hline & $(0.00)$ & $(0.00)$ & $(0.00)$ & $(0.00)$ & $(0.00)$ & $(0.00)$ & $(0.00)$ \\
\hline \multirow[t]{2}{*}{$\tau(-\Delta i)$} & $0.33^{* * *}$ & $0.33^{* * *}$ & $0.27^{* * *}$ & 0.20 & $-0.63^{* * *}$ & $0.38^{* * *}$ & $0.55^{* * *}$ \\
\hline & $(0.01)$ & $(0.02)$ & $(0.02)$ & $(0.21)$ & $(0.13)$ & $(0.07)$ & $(0.11)$ \\
\hline \multirow[t]{2}{*}{$L \cdot \tau(-\Delta i)$} & $-0.01^{* * *}$ & -0.02 & $-0.03^{* * *}$ & 0.06 & $-0.18^{* *}$ & & $0.16^{*}$ \\
\hline & $(0.00)$ & $(0.01)$ & $(0.01)$ & $(0.14)$ & (0.09) & & $(0.09)$ \\
\hline \multirow[t]{2}{*}{$P \cdot \tau(-\Delta i)$} & $0.04^{* * *}$ & $0.05^{* * *}$ & $0.05^{* * *}$ & & & & \\
\hline & $(0.01)$ & $(0.02)$ & $(0.02)$ & & & & \\
\hline \multirow[t]{2}{*}{$L \cdot P \cdot \tau(-\Delta i)$} & & 0.01 & 0.00 & & & & \\
\hline & & $(0.01)$ & $(0.01)$ & & & & \\
\hline \multirow[t]{2}{*}{$R A$} & & & $0.48^{* * * *}$ & & $1.65^{* * *}$ & & \\
\hline & & & $(0.01)$ & & $(0.02)$ & & \\
\hline \multirow[t]{2}{*}{$L \cdot R A$} & & & $0.11^{* * *}$ & & $0.22^{* * *}$ & & \\
\hline & & & $(0.00)$ & & $(0.01)$ & & \\
\hline \multirow[t]{2}{*}{$P \cdot R A$} & & & $-0.14^{* * *}$ & & & & \\
\hline & & & $(0.01)$ & & & & \\
\hline$R^{2}$ & $6.2 \%$ & $6.2 \%$ & $25.3 \%$ & $0.0 \%$ & $80.7 \%$ & $0.02 \%$ & $0.02 \%$ \\
\hline$N$ & 614,284 & 614,283 & 614,280 & 180,081 & 180,079 & 180,082 & 180,081 \\
\hline
\end{tabular}
5 , and $1 \%$ levels. To be included in the sample, bonds are required to have face value greater than $\$ 100 \mathrm{MM}$ and time-to-maturity longer than 3 years. 


\section{Table 4: Validation of Duration Regression Model}

This table reports the regression results for the model in Table 3 using a simulated sample. The simulation is based on the model in equation (2). We regress modified duration calculated from the simulated sample on log leverage, priority, and the interaction between $\log$ leverage and priority. The value of $\log \operatorname{assets}(\log (\mathrm{V}))$ is randomly drawn from $N\left(1.26,0.73^{2}\right)$ where the mean (1.26) and standard deviation $(0.73)$ match those of the sample in Table 3. The face value of total debt $K\left(=K_{s}+K_{j}\right)$ is assumed to be one, and the amount of junior debt $\left(K_{j}\right)$ is determined by a logit function, $\exp (x) /(1+\exp (x))$, where the random variable $x$ is drawn from the Gaussian distribution. The mean and standard deviations of the Gaussian distribution are chosen to match the sample moments of $K_{j}$ in the data. The parameter values are $r=5 \% \sigma_{v}=20 \%, \tau=5, q=0.20, v=$ $2 \%, m=7 \%$, and $\rho=0$. We draw a total of 100,000 observations and discard extreme observations with very high leverage ratios $(K / V<=1.5)$.

\begin{tabular}{ccccc}
\hline \multirow{2}{*}{$\tau(-\Delta i)$} & \multicolumn{2}{c}{ Bond } & & Equity \\
\cline { 2 - 3 }$L \cdot \tau(-\Delta i)$ & 0.31 & 0.02 & & -4.30 \\
& $(0.00)$ & $(0.00)$ & & $(0.02)$ \\
$P \cdot \tau(-\Delta i)$ & -0.10 & -0.32 & & -1.93 \\
& $(0.00)$ & $(0.00)$ & & $(0.01)$ \\
$L \cdot P \cdot \tau(-\Delta i)$ & 0.18 & 0.56 & \\
& $(0.00)$ & $(0.00)$ & \\
$R^{2}$ & & 0.30 & \\
\hline
\end{tabular}




\section{Table 5: Duration of Bonds and Equity: Within-Firm Difference Analysis}

For bond and equity returns $\left(R^{m}\right)$, we run the following regression:

$$
R_{t}^{m}-R_{t}^{n}=\alpha+\beta\left(-\Delta i_{t}\right)+\gamma\left(\tau_{t}^{m}-\tau_{t}^{n}\right)\left(-\Delta i_{t}\right)+\varepsilon_{t}
$$

where $R^{n}$ is a return on a bond issued by the same firm whose priority is higher than that of security $m$. $\tau^{m}-\tau^{n}$ is the difference in time-to-maturity between the securities $m$ and $n$. When $m$ is a bond, the bond $n$ is required to be of the same type as $m$ in terms of callability, convertibility, and coupon type (floating versus fixed rate). When $m$ is equity, we consider all bonds issued by the same firm for $n$ and the difference in time-tomaturity is just $-\tau^{n}$. Estimation is based on a pooled regression for the sample period from 1980 to 2007 . To be included in the sample, bonds are required to have more than \$100MM outstanding and time-to-maturity longer than 3 years. *, **, and $* * *$ denote statistical significance at the 10,5 , and $1 \%$ levels. Numbers in parentheses are White robust standard errors.

\begin{tabular}{|c|c|c|c|c|c|c|}
\hline \multirow{3}{*}{ Intercept } & \multicolumn{4}{|c|}{ Bond } & \multicolumn{2}{|c|}{ Equity } \\
\hline & $0.00^{* * *}$ & $0.00^{* * * *}$ & $0.00^{* * * *}$ & $0.00^{* * *}$ & $0.00^{* * *}$ & $0.00^{* * * *}$ \\
\hline & $(0.00)$ & $(0.00)$ & $(0.00)$ & $(0.00)$ & $(0.00)$ & $(0.00)$ \\
\hline \multirow[t]{2}{*}{$-\Delta i$} & $-0.29^{* * *}$ & $-0.25^{* * *}$ & $-0.25^{* * *}$ & $-0.25^{* * *}$ & $-1.68^{* * *}$ & $-1.40^{* * *}$ \\
\hline & $(0.02)$ & $(0.02)$ & $(0.02)$ & $(0.02)$ & $(0.03)$ & $(0.07)$ \\
\hline \multirow[t]{2}{*}{$-\left(\tau^{m}-\tau^{n}\right) \cdot \Delta i$} & & $0.15^{* * *}$ & & $0.12^{* * *}$ & & $0.03^{* * *}$ \\
\hline & & $(0.00)$ & & $(0.01)$ & & $(0.01)$ \\
\hline$R^{2}$ & $0.1 \%$ & $0.5 \%$ & $0.4 \%$ & $0.5 \%$ & $0.4 \%$ & $0.4 \%$ \\
\hline$N$ & 318,124 & 318,123 & 318,118 & 318,117 & 924,794 & 924,793 \\
\hline Bond Type Fixed Effect & No & No & Yes & Yes & No & No \\
\hline
\end{tabular}




\section{Table 6: Duration of Bonds and Equity: Aggregate Level Analysis}

In Panel A, we report duration estimates for corporate bond indices and issuer-level credit rating equity portfolios for the sample period from 1985 to 2010. The bond indices are drawn from Citigroup's Yieldbook. The equity credit rating portfolios are constructed from the CRSP universe using S\&P credit ratings. We estimate duration by regressing bond index and equity portfolio returns on the negative of five-year, constant maturity Treasury yield changes. In Panel B, we report duration estimates for senior bonds (High), junior bonds (Low), and equity portfolios for each issuer-level credit rating group. As in Panel A, we estimate duration by regressing portfolio returns on the negative of five-year, constant maturity Treasury yield changes. The sample consists of firms that have both high and low priority bonds with time-to-maturity longer than 3 years. The sample period is from 1980 to 2007 . *,**, and *** denote statistical significance at the 10,5 , and $1 \%$ levels. The numbers in parentheses are White robust standard errors.

Panel A: Bond and Equity Indices

\begin{tabular}{cccccccc}
\hline & \multicolumn{7}{c}{ Bond } \\
& AAA & AA & A & BBB & BB & B & CCC \\
\cline { 2 - 8 } & $3.21^{* * * *}$ & $3.22^{* * * *}$ & $3.08^{* * *}$ & $2.52^{* * *}$ & $1.88^{* * *}$ & 0.77 & -0.87 \\
& $(0.31)$ & $(0.31)$ & $(0.35)$ & $(0.33)$ & $(0.43)$ & $(0.54)$ & $(1.14)$ \\
$R^{2}$ & 0.34 & 0.34 & 0.26 & 0.18 & 0.07 & 0.01 & 0.00 \\
\hline \multirow{7}{*}{} & AAA & AA & A & BBB & BB & B & CCC \\
& 1.16 & 1.09 & 0.80 & 0.70 & -0.52 & -1.50 & -3.01 \\
$-\Delta i$ & $(0.82)$ & $(0.91)$ & $(0.87)$ & $(0.89)$ & $(1.20)$ & $(1.48)$ & $(2.08)$ \\
& 0.01 & 0.00 & 0.00 & 0.00 & 0.00 & 0.00 & 0.01 \\
\hline
\end{tabular}

Panel B: Bond and Equity Portfolios Sorted on Issuer-Level Ratings

\begin{tabular}{|c|c|c|c|c|c|c|c|c|c|}
\hline & \multicolumn{3}{|c|}{ AAA } & \multicolumn{3}{|c|}{ AA } & \multicolumn{3}{|c|}{ A } \\
\hline \multirow{3}{*}{$-\Delta i$} & High & Low & Equity & High & Low & Equity & High & Low & Equity \\
\hline & $3.86^{* * * *}$ & $2.00^{* * * *}$ & 0.31 & $3.97^{* * * *}$ & $3.02^{* * *}$ & 0.61 & $3.83^{* * * *}$ & $3.80^{* * * *}$ & -0.08 \\
\hline & $(0.46)$ & $(0.69)$ & (1.02) & $(0.49)$ & $(0.69)$ & $(0.90)$ & $(0.49)$ & $(0.52)$ & (1.04) \\
\hline$R^{2}$ & 0.37 & 0.04 & 0.00 & 0.32 & 0.13 & 0.00 & 0.31 & 0.28 & 0.00 \\
\hline \multirow[t]{3}{*}{$\begin{array}{l}\text { Avg. \# of } \\
\text { Securities }\end{array}$} & 212 & 13 & 8 & 78 & 46 & 32 & 535 & 425 & 149 \\
\hline & \multicolumn{3}{|c|}{ BBB } & \multicolumn{3}{|c|}{$\mathrm{BB}$} & \multicolumn{3}{|c|}{ B } \\
\hline & High & Low & Equity & High & Low & Equity & High & Low & Equity \\
\hline \multirow[t]{2}{*}{$-\Delta i$} & $3.21^{* * * *}$ & $3.00^{* * * *}$ & 0.24 & $1.70^{* * * *}$ & 1.12 & -1.76 & 0.69 & 0.44 & -3.52 \\
\hline & $(0.49)$ & $(0.52)$ & $(1.23)$ & $(0.57)$ & $(0.75)$ & $(1.61)$ & (1.12) & $(1.58)$ & $(2.48)$ \\
\hline$R^{2}$ & 0.23 & 0.20 & 0.00 & 0.07 & 0.02 & 0.01 & 0.00 & 0.00 & 0.01 \\
\hline $\begin{array}{l}\text { Avg. \# of } \\
\text { Securities }\end{array}$ & 694 & 485 & 205 & 337 & 191 & 182 & 119 & 104 & 126 \\
\hline
\end{tabular}




\section{Table 7: Regression Analysis of the Correlation between Equity and Bond Returns}

The dependent variable is the correlation estimated from a 36-month rolling window of monthly equity and bond returns. In the columns labeled Our Sample, the equity return is the value-weighted average of stock returns for all non-financial firms available in our sample. In the columns labeled CRSP/Compustat, the equity return is the value-weighted average of stock returns from the CRSP/Compustat universe. The bond return is the return on 5-year Treasury bonds. $\operatorname{ILLIQ}(S)$ is a measure of equity market illiquidity, which is the capitalizationbased proportion of zero daily returns across all firms, aggregated over the month, following Bekaert, Harvey, and Lundblad (2007). ILLIQ $(B)$ is a monthly average of quoted bid-ask spreads of off-the-run bonds across all maturities, following Baele, Bekaert and Inghelbrecht (2010). BDMA is book debt over the market value of assets of the firms in each sample. $D Y$ is the dividend yield based on Fama and French (1988). DS is the yield spread between BBB and AAA corporate bonds available from the Federal Reserve Economic Database. TS is the term spread between 10-year and one-year, constant maturity Treasury rates and $T B$ is the 3-month T-bill rate. All explanatory variables are standardized using the sample mean and standard deviations. The sample period is from 1990 to $2007 . * * *$, and $* * *$ denote statistical significance at the 10,5 , and $1 \%$ levels. The numbers in parentheses are Newey-West standard errors.

\begin{tabular}{|c|c|c|c|c|c|c|}
\hline \multirow{3}{*}{ Intercept } & \multicolumn{3}{|c|}{ Our Sample } & \multicolumn{3}{|c|}{ CRSP/Compustat } \\
\hline & $0.55^{* * *}$ & $0.56^{* * *}$ & $0.54^{* * *}$ & $0.52^{* * * *}$ & $0.48^{* * * *}$ & $0.47^{* * * *}$ \\
\hline & $(0.05)$ & $(0.04)$ & $(0.05)$ & $(0.05)$ & $(0.04)$ & $(0.04)$ \\
\hline \multirow[t]{2}{*}{ VIX } & 0.05 & $0.06^{* * *}$ & 0.02 & 0.03 & -0.01 & -0.01 \\
\hline & $(0.03)$ & $(0.02)$ & $(0.01)$ & $(0.03)$ & $(0.02)$ & $(0.01)$ \\
\hline \multirow[t]{2}{*}{$\operatorname{ILLIQ}(\mathrm{S})$} & $-0.22^{* * *}$ & 0.06 & -0.03 & $-0.22^{* * *}$ & $-0.13^{* *}$ & $-0.14^{* *}$ \\
\hline & $(0.07)$ & $(0.06)$ & $(0.06)$ & $(0.07)$ & $(0.05)$ & $(0.07)$ \\
\hline \multirow[t]{2}{*}{ ILLIQ(B) } & $0.33^{* * *}$ & $0.56^{* * *}$ & $0.25^{* * *}$ & $0.33^{* * *}$ & $0.43^{* * * *}$ & 0.06 \\
\hline & $(0.12)$ & $(0.12)$ & $(0.10)$ & $(0.12)$ & $(0.10)$ & $(0.10)$ \\
\hline \multirow[t]{2}{*}{$\operatorname{ILLIQ}(\mathrm{S}) * \operatorname{ILLIQ}(\mathrm{B})$} & $-1.18^{* * *}$ & $-0.83^{* * *}$ & $-0.99^{* * * *}$ & $-1.13^{* * *}$ & $-0.81^{* * *}$ & $-1.02^{* * *}$ \\
\hline & $(0.11)$ & $(0.08)$ & $(0.07)$ & $(0.10)$ & $(0.08)$ & $(0.09)$ \\
\hline \multirow[t]{2}{*}{ BDMA } & & $-0.20^{* * *}$ & $-0.11^{* * * *}$ & & $-0.09^{* * *}$ & $-0.04^{* *}$ \\
\hline & & $(0.03)$ & $(0.04)$ & & $(0.01)$ & $(0.02)$ \\
\hline \multirow[t]{2}{*}{ DY } & & & -0.08 & & & -0.03 \\
\hline & & & $(0.06)$ & & & $(0.07)$ \\
\hline \multirow[t]{2}{*}{ DS } & & & $0.06^{* * *}$ & & & $0.06^{* * *}$ \\
\hline & & & $(0.02)$ & & & $(0.02)$ \\
\hline \multirow[t]{2}{*}{ TS } & & & 0.04 & & & 0.00 \\
\hline & & & $(0.02)$ & & & $(0.03)$ \\
\hline \multirow[t]{2}{*}{$\mathrm{TB}$} & & & $0.17^{* * *}$ & & & $0.16^{* * *}$ \\
\hline & & & $(0.04)$ & & & $(0.05)$ \\
\hline $\mathrm{N}$ & 216 & 216 & 216 & 216 & 216 & 216 \\
\hline $\mathrm{R}^{2}$ & $84.3 \%$ & $90.7 \%$ & $93.6 \%$ & $81.8 \%$ & $86.7 \%$ & $92.3 \%$ \\
\hline
\end{tabular}




\section{Table 8: Estimation of Bond Factor Loadings}

This table provides results from regressions of equity and bond returns on stock and bond market factors for six issuer-level credit rating portfolios. The equity and bond rating portfolios are value-weighted using the market values of equity and bonds, respectively. The stock market factors are the returns on the market portfolio, the small-minus-big factor, and high-minus-low factor from Ken French's website. We use two sets of bond market factors: (Term, Def1) in Panel A and (Term, Def2) in Panel B. Term is the return on long-term government bonds (the average of 10-, 20-, and 30-year T-bond returns) minus the 1-year T-bond return. Defl is the return on aggregate corporate bonds (the value-weighted average of investment and high-yield index returns from Citi's Yieldbook) minus the return on long-term government bonds used in Term. Def2 is the return on aggregate corporate bonds minus 5-year T-bond returns. Panel $\mathrm{C}$ provides the differences in coefficients on Term and Def between Panel A and Panel B from GMM estimation with an identity weighting matrix with a Bartlett kernel of 4 lags. The reported $p$-values are based on the one-sided test that the differences are less than zero. *, **, and *** denote statistical significance at the 10,5 , and $1 \%$ levels. The numbers in parentheses in Panels A and B are White robust standard errors and those in Panel C are from the GMM estimation. The sample period is from 1990 to 2007.

Panel A: DEF1 = Corporate Bond Index - Long-Term Treasury

\begin{tabular}{|c|c|c|c|c|c|c|c|c|c|c|c|c|}
\hline & \multicolumn{2}{|c|}{ AAA } & \multicolumn{2}{|c|}{ AA } & \multicolumn{2}{|c|}{ A } & \multicolumn{2}{|c|}{ BBB } & \multicolumn{2}{|c|}{ BB } & \multicolumn{2}{|c|}{ B } \\
\hline & Equity & Bond & Equity & Bond & Equity & Bond & Equity & Bond & Equity & Bond & Equity & Bond \\
\hline \multirow[t]{2}{*}{ Const } & $0.00^{* * * *}$ & $0.00^{* * * *}$ & 0.00 & $0.00^{* * * *}$ & 0.00 & $0.00^{* * *}$ & $0.00^{* * * *}$ & $0.00^{* * * *}$ & $0.00^{* *}$ & $0.00^{*}$ & $-0.01^{* * * *}$ & 0.00 \\
\hline & $(0.00)$ & $(0.00)$ & $(0.00)$ & $(0.00)$ & $(0.00)$ & $(0.00)$ & $(0.00)$ & $(0.00)$ & $(0.00)$ & $(0.00)$ & $(0.00)$ & $(0.00)$ \\
\hline \multirow[t]{2}{*}{$M k t$} & $0.72^{* * *}$ & 0.00 & $0.81^{* * * *}$ & 0.00 & $0.96^{* * *}$ & $-0.02^{* * * *}$ & $0.98^{* * *}$ & 0.00 & $1.28^{* * * *}$ & $0.07^{* * *}$ & $1.54^{* * *}$ & $0.13^{* * * *}$ \\
\hline & $(0.05)$ & $(0.01)$ & $(0.04)$ & $(0.01)$ & $(0.03)$ & $(0.01)$ & $(0.04)$ & $(0.01)$ & $(0.05)$ & $(0.02)$ & (0.09) & $(0.04)$ \\
\hline \multirow[t]{2}{*}{$\operatorname{SmB}$} & $-0.52^{* * * *}$ & $-0.02^{* *}$ & $-0.26^{* * * *}$ & $-0.02^{* *}$ & $-0.06^{* *}$ & -0.01 & -0.02 & -0.01 & $0.49^{* * * *}$ & $0.06^{* * *}$ & $0.62^{* * *}$ & $0.11^{* * * *}$ \\
\hline & $(0.05)$ & $(0.01)$ & $(0.04)$ & $(0.01)$ & $(0.03)$ & $(0.01)$ & $(0.03)$ & $(0.01)$ & $(0.04)$ & $(0.01)$ & $(0.08)$ & $(0.03)$ \\
\hline \multirow[t]{2}{*}{$H m L$} & -0.04 & -0.01 & $0.09^{*}$ & $-0.02^{*}$ & $0.11^{* * * *}$ & $-0.02^{* * * *}$ & $0.13^{* * *}$ & $-0.02^{* *}$ & $0.22^{* * *}$ & -0.02 & $-0.30^{* * *}$ & $-0.08^{*}$ \\
\hline & $(0.06)$ & $(0.01)$ & $(0.05)$ & $(0.01)$ & $(0.03)$ & $(0.01)$ & $(0.04)$ & $(0.01)$ & $(0.06)$ & $(0.02)$ & $(0.11)$ & $(0.04)$ \\
\hline \multirow[t]{2}{*}{ Term } & -0.07 & $0.56^{* * *}$ & -0.07 & $0.74^{* * * *}$ & $-0.15^{*}$ & $0.81^{* * *}$ & 0.16 & $0.95^{* * * *}$ & -0.21 & $1.01^{* * *}$ & $0.76^{* * * *}$ & $1.58^{* * * *}$ \\
\hline & $(0.16)$ & $(0.03)$ & $(0.13)$ & $(0.03)$ & $(0.09)$ & $(0.02)$ & $(0.11)$ & $(0.03)$ & $(0.15)$ & $(0.05)$ & $(0.29)$ & $(0.12)$ \\
\hline \multirow[t]{2}{*}{ Defl } & -0.08 & $0.27^{* * *}$ & -0.15 & $0.36^{* * *}$ & $-0.24^{* * *}$ & $0.49^{* * *}$ & $0.27^{*}$ & $0.81^{* * *}$ & -0.13 & $1.36^{* * *}$ & $1.35^{* * *}$ & $2.43^{* * *}$ \\
\hline & $(0.23)$ & $(0.04)$ & $(0.20)$ & $(0.05)$ & $(0.13)$ & $(0.03)$ & $(0.17)$ & $(0.05)$ & $(0.22)$ & $(0.07)$ & $(0.42)$ & $(0.17)$ \\
\hline$N$ & 216 & 216 & 216 & 216 & 216 & 216 & 216 & 216 & 216 & 216 & 216 & 216 \\
\hline$R^{2}$ & $69.8 \%$ & $85.6 \%$ & $76.1 \%$ & $88.5 \%$ & $90.6 \%$ & $94.1 \%$ & $87.3 \%$ & $89.3 \%$ & $88.2 \%$ & $81.1 \%$ & $82.8 \%$ & $71.9 \%$ \\
\hline
\end{tabular}


Panel B: DEF2 = Corporate Bond Index - Five-Year Treasury

\begin{tabular}{|c|c|c|c|c|c|c|c|c|c|c|c|c|}
\hline & \multicolumn{2}{|c|}{ AAA } & \multicolumn{2}{|c|}{ AA } & \multicolumn{2}{|c|}{ A } & \multicolumn{2}{|c|}{ BBB } & \multicolumn{2}{|c|}{$\mathrm{BB}$} & \multicolumn{2}{|c|}{ B } \\
\hline & Equity & Bond & Equity & Bond & Equity & Bond & Equity & Bond & Equity & Bond & Equity & Bond \\
\hline \multirow[t]{2}{*}{ const } & $0.00^{* * *}$ & $0.00^{* * * *}$ & 0.00 & $0.00^{* * * *}$ & 0.00 & $0.00^{* * *}$ & 0.00 & $0.00^{* * *}$ & $0.00^{* *}$ & $0.00^{* * *}$ & $-0.01^{* *}$ & 0.00 \\
\hline & $(0.00)$ & $(0.00)$ & $(0.00)$ & $(0.00)$ & $(0.00)$ & $(0.00)$ & $(0.00)$ & $(0.00)$ & $(0.00)$ & $(0.00)$ & $(0.00)$ & $(0.00)$ \\
\hline \multirow[t]{2}{*}{ MktRf } & $0.73^{* * * *}$ & $0.03^{* * * *}$ & $0.83^{* * *}$ & $0.04^{* * * *}$ & $0.95^{* * *}$ & 0.01 & $0.97^{* * * *}$ & $0.02^{*}$ & $1.26^{* * * *}$ & $0.08^{* * *}$ & $1.49^{* * *}$ & $0.12^{* * * *}$ \\
\hline & $(0.05)$ & $(0.01)$ & $(0.04)$ & $(0.01)$ & $(0.03)$ & $(0.01)$ & $(0.04)$ & $(0.01)$ & $(0.05)$ & $(0.02)$ & $(0.09)$ & $(0.04)$ \\
\hline \multirow[t]{2}{*}{$S m B$} & $-0.51^{* * * *}$ & -0.01 & $-0.25^{* * *}$ & -0.01 & $-0.07^{* *}$ & 0.00 & -0.02 & 0.00 & $0.49^{* * * *}$ & $0.06^{* * *}$ & $0.59^{* * *}$ & $0.10^{* * * *}$ \\
\hline & $(0.05)$ & $(0.01)$ & $(0.04)$ & $(0.01)$ & $(0.03)$ & $(0.01)$ & $(0.03)$ & $(0.01)$ & $(0.05)$ & $(0.02)$ & (0.09) & $(0.04)$ \\
\hline \multirow[t]{2}{*}{$H m L$} & -0.04 & 0.01 & $0.10^{* *}$ & 0.01 & $0.10^{* * * *}$ & 0.00 & $0.13^{* * * *}$ & -0.01 & $0.21^{* * *}$ & -0.01 & $-0.33^{* * * *}$ & $-0.09^{*}$ \\
\hline & $(0.06)$ & $(0.01)$ & $(0.05)$ & $(0.01)$ & $(0.03)$ & $(0.01)$ & $(0.04)$ & $(0.02)$ & $(0.06)$ & $(0.02)$ & $(0.11)$ & $(0.05)$ \\
\hline \multirow[t]{2}{*}{ Term } & -0.03 & $0.39^{* * * *}$ & 0.01 & $0.52^{* * * *}$ & 0.00 & $0.52^{* * *}$ & 0.01 & $0.47^{* * *}$ & $-0.13^{* *}$ & $0.21^{* * *}$ & -0.03 & $0.15^{* * * *}$ \\
\hline & $(0.06)$ & $(0.01)$ & $(0.05)$ & $(0.02)$ & $(0.04)$ & $(0.01)$ & $(0.05)$ & $(0.02)$ & $(0.06)$ & $(0.02)$ & $(0.12)$ & $(0.05)$ \\
\hline \multirow[t]{2}{*}{ Def2 } & -0.12 & 0.04 & -0.21 & 0.05 & -0.12 & $0.21^{* * *}$ & $0.25^{*}$ & $0.50^{* * *}$ & 0.02 & $1.03^{* * *}$ & $1.36^{* * *}$ & $1.99^{* * * *}$ \\
\hline & $(0.21)$ & $(0.04)$ & $(0.17)$ & $(0.05)$ & $(0.12)$ & $(0.04)$ & $(0.15)$ & $(0.05)$ & $(0.20)$ & $(0.08)$ & $(0.37)$ & $(0.16)$ \\
\hline$N$ & 216 & 216 & 216 & 216 & 216 & 216 & 216 & 216 & 216 & 216 & 216 & 216 \\
\hline$R^{2}$ & $69.8 \%$ & $82.9 \%$ & $76.2 \%$ & $85.6 \%$ & $90.5 \%$ & $89.6 \%$ & $87.3 \%$ & $81.4 \%$ & $88.2 \%$ & $73.0 \%$ & $83.0 \%$ & $67.8 \%$ \\
\hline
\end{tabular}

Panel C: Cross-Equation Difference

\begin{tabular}{|c|c|c|c|c|c|c|c|c|c|c|c|c|}
\hline & \multicolumn{2}{|c|}{ AAA } & \multicolumn{2}{|c|}{ AA } & \multicolumn{2}{|c|}{ A } & \multicolumn{2}{|c|}{ BBB } & \multicolumn{2}{|c|}{$\mathrm{BB}$} & \multicolumn{2}{|c|}{ B } \\
\hline & Equity & Bond & Equity & Bond & Equity & Bond & Equity & Bond & Equity & Bond & Equity & Bond \\
\hline Term & -0.04 & $0.17^{* * *}$ & -0.08 & $0.22^{* * *}$ & -0.14 & $0.29^{* * * *}$ & 0.16 & $0.48^{* * *}$ & -0.08 & $0.80^{* * * *}$ & $0.78^{* * * *}$ & $1.43^{* * *}$ \\
\hline & $(0.15)$ & $(0.04)$ & $(0.15)$ & $(0.05)$ & (0.09) & $(0.04)$ & $(0.15)$ & $(0.05)$ & $(0.15)$ & $(0.05)$ & $(0.27)$ & $(0.13)$ \\
\hline$p$-value & 0.61 & 0.00 & 0.71 & 0.00 & 0.95 & 0.00 & 0.14 & 0.00 & 0.71 & 0.00 & 0.00 & 0.00 \\
\hline Def & 0.04 & $0.23^{* * *}$ & 0.07 & $0.31^{* * *}$ & -0.12 & $0.28^{* * *}$ & 0.03 & $0.31^{* * *}$ & -0.15 & $0.32^{* * * *}$ & -0.01 & $0.45^{* * *}$ \\
\hline & $(0.16)$ & $(0.05)$ & $(0.13)$ & $(0.05)$ & $(0.13)$ & $(0.04)$ & $(0.12)$ & $(0.06)$ & $(0.15)$ & $(0.07)$ & $(0.23)$ & $(0.13)$ \\
\hline$p$-value & 0.41 & 0.00 & 0.31 & 0.00 & 0.82 & 0.00 & 0.42 & 0.00 & 0.85 & 0.00 & 0.51 & 0.00 \\
\hline
\end{tabular}




\section{Table 9: Time-Variation in Expected Returns}

This table provides results from the predictive regressions of equity, bond, and asset excess returns on the dividend yield, term spread, and yield spread between high-yield corporate bonds and short-term government bonds. The equity, bond, and asset returns are value-weighted aggregate returns based on all firms in the sample with an available issuer-level credit rating, as reported in Table 6 . The dividend yield, $d p$, is estimated following Fama and French (1988). The term-spread, ys, is 10-year, constant maturity Treasury yield minus the 3-month T-bill yield. The yield spread between high-yield corporate bonds and short-term government bonds is the yield on the high-yield market index from Citi's Yieldbook minus the 3-month T-bill rate. The column Equity-Asset reports the difference in coefficients between the equity and asset predictive regressions, estimated from the GMM with an identity weighting matrix. *, **, and *** denote statistical significance at the 10,5 , and $1 \%$ levels. The numbers in parentheses are the Newey-West standard errors with 4 lags, and the sample period is from 1991 to 2007.

\begin{tabular}{ccccc}
\hline \multirow{2}{*}{ const } & Equity & Bond & Asset & Equity-Asset \\
\cline { 2 - 5 } & -0.01 & $-0.01^{* * *}$ & -0.01 & \\
& $(0.01)$ & $(0.00)$ & $(0.01)$ & \\
$d p$ & $1.35^{* *}$ & $0.30^{*}$ & $1.10^{* * *}$ & $0.24^{* *}$ \\
& $(0.52)$ & $(0.17)$ & $(0.42)$ & $(0.11)$ \\
$y s$ & -0.14 & -0.05 & -0.11 & -0.03 \\
& $(0.35)$ & $(0.11)$ & $(0.28)$ & $(0.07)$ \\
def & -0.20 & $0.11^{*}$ & -0.14 & $-0.07^{*}$ \\
& $(0.18)$ & $(0.06)$ & $(0.15)$ & $(0.04)$ \\
$N$ & 203 & 203 & 203 & \\
$R^{2}$ & $2.61 \%$ & $4.53 \%$ & $2.36 \%$ & \\
\hline
\end{tabular}




\section{Table 10: Understanding Default and Term Spreads}

This table provides results from predictive regressions of equity excess returns on the dividend yield, term spread, and two different measures of the default spread. The dividend yield, $d p$, is estimated following Fama and French (1988). The term-spread, ys, is the 10-year, constant maturity Treasury yield minus the 3-month Tbill yield. The first default spread measure, $\operatorname{def}(K S)$, based on Keim and Stambaugh (1986), is the difference between the yield on a high-yield bond index minus the 3 -month T-bill rate. The second measure, $\operatorname{def}(F F)$, based on Fama and French (1986), is the difference between the yields on a high-yield bond index and a AAArated corporate bond index. The column KS-FF reports the differences in coefficients between the regressions based on the Keim and Stambaugh and Fama and French measures, estimated using GMM with an identity weighting matrix. The reported $p$-values are based on the one-sided test that the differences are less than zero. *, $* *$, and $* * *$ denote statistical significance at the 10,5, and 1\% levels. The numbers in parentheses are NeweyWest standard errors, and the sample period is from 1991 to 2007.

\begin{tabular}{|c|c|c|c|c|}
\hline & $\mathrm{KS}$ & FF & & KS - FF \\
\hline \multirow[t]{2}{*}{ const } & -0.01 & -0.01 & $d p(K S)-d p(F F)$ & -0.13 \\
\hline & $(0.01)$ & $(0.01)$ & & $(0.09)$ \\
\hline \multirow[t]{2}{*}{$d p$} & $1.35^{* *}$ & $1.48^{* * *}$ & $p$-value & 0.92 \\
\hline & $(0.52)$ & $(0.53)$ & & \\
\hline \multirow[t]{2}{*}{$y s$} & -0.14 & -0.36 & $y s(K S)-y s(F F)$ & 0.22 \\
\hline & $(0.35)$ & $(0.24)$ & & $(0.19)$ \\
\hline \multirow[t]{2}{*}{$\operatorname{def}(K S)$} & -0.20 & & $p$-value & 0.13 \\
\hline & $(0.18)$ & & & \\
\hline \multirow[t]{2}{*}{$\operatorname{def}(F F)$} & & -0.28 & $\operatorname{def}(K S)-\operatorname{def}(F F)$ & $0.08^{* *}$ \\
\hline & & $(0.21)$ & & $(0.04)$ \\
\hline$N$ & 203 & 203 & $p$-value & 0.03 \\
\hline$R^{2}$ & $2.61 \%$ & $2.84 \%$ & & \\
\hline
\end{tabular}




\section{Table 11: Inflation and Asset Returns}

This table reports results from regressions of quarterly aggregate returns on contemporaneous inflation and contemporaneous and future real activity (GNP growth and Industrial production growth):

$$
R_{t}^{i}=\alpha+\beta \pi_{t}+\gamma_{0} X_{t}+\gamma_{1} X_{t+j}+\varepsilon_{t}
$$

where $R_{t}^{i}$ is aggregate returns on equity or assets, $\pi_{t}$ is the inflation rate, $X_{t}$ is contemporaneous GNP growth or industrial production growth, and $X_{t+j}$ is future GNP or industrial production (IP) growth. In Panels A and B, the dependent variables are the aggregate equity and asset returns $\left(R_{t}^{E}\right.$ and $R_{t}^{V}$ ), respectively. Both the equity and asset aggregated returns are constructed from firms with asset return data available. In the columns EquityAsset in Panel A, we report the difference in the coefficients on inflation between the equity and asset level regressions, estimated using GMM with an identity weighting matrix. The reported p-values are based on the one-sided test that the differences are less than zero. ${ }^{*}, * *$, and $* * *$ denote statistical significance at the 10,5 , and $1 \%$ levels. The numbers in parentheses are the heteroskedasticity robust standard errors. The sample period is from 1980 to 2007.

Panel A: Equity

\begin{tabular}{cccccccccc}
\hline & & & & & & & & \multicolumn{2}{c}{ Equity-Asset } \\
\cline { 6 - 10 }$\pi_{t}$ & $G N P_{t+1}$ & $G N P_{t+2}$ & $G N P_{t+3}$ & $I P_{t+1}$ & $I P_{t+2}$ & $I P_{t+3}$ & $R^{2}$ & $\pi_{t}$ & $p$-value \\
\hline 0.33 & & & & & & & $0.2 \%$ & 0.05 & 0.39 \\
$(0.74)$ & & & & & & & & $(0.18)$ & \\
0.54 & 0.52 & & & 0.59 & & & $3.0 \%$ & 0.12 & 0.28 \\
$(0.75)$ & $(1.05)$ & & & $(0.56)$ & & & & $(0.20)$ & \\
$1.28^{*}$ & 0.08 & 0.16 & & 0.86 & $1.39^{* *}$ & & $13.5 \%$ & 0.28 & 0.06 \\
$(0.75)$ & $(1.04)$ & $(0.60)$ & & $(1.13)$ & $(0.56)$ & & & $(0.18)$ & \\
$1.46^{* *}$ & -0.33 & $2.53^{* *}$ & 0.89 & 1.32 & 0.31 & -0.90 & $17.4 \%$ & $0.32^{*}$ & 0.04 \\
$(0.75)$ & $(1.05)$ & $(1.19)$ & $(0.61)$ & $(1.15)$ & $(0.61)$ & $(0.57)$ & & $(0.18)$ & \\
\hline
\end{tabular}

Panel B: Asset

\begin{tabular}{cccccccc}
\hline$\pi_{t}$ & $G N P_{t+1}$ & $G N P_{t+2}$ & $G N P_{t+3}$ & $I P_{t+1}$ & $I P_{t+2}$ & $I P_{t+3}$ & $R^{2}$ \\
\hline 0.28 & & & & & & & $0.2 \%$ \\
$(0.58)$ & & & & & & & \\
0.42 & 0.40 & & & 0.39 & & & $2.4 \%$ \\
$(0.59)$ & $(0.83)$ & & & $(0.44)$ & & & \\
$1.00^{*}$ & 0.05 & 0.06 & & 0.68 & $1.08^{* *}$ & & $12.7 \%$ \\
$(0.59)$ & $(0.81)$ & $(0.48)$ & & $(0.89)$ & $(0.44)$ & & \\
$1.14^{*}$ & -0.28 & $2.10^{* *}$ & 0.67 & 1.07 & 0.17 & $-0.79^{*}$ & $17.3 \%$ \\
$(0.59)$ & $(0.82)$ & $(0.93)$ & $(0.48)$ & $(0.90)$ & $(0.48)$ & $(0.44)$ & \\
\hline
\end{tabular}




\section{Table 12: Beta of Corporate Bonds}

This table reports estimation results for the following regressions:

$$
\begin{aligned}
& R_{t+1}^{B_{i}}-R_{t}^{F}=\alpha+\beta\left(R_{t+1}^{M}-R_{t}^{F}\right)+\varepsilon_{t+1} \\
& R_{t+1}^{B_{i}}-R_{t}^{F}=\alpha+\beta_{1}\left(R_{t+1}^{V_{M}}-R_{t}^{F}\right)+\beta_{2}\left(R_{t+1}^{M}-R_{t+1}^{V_{M}}\right)+\varepsilon_{t+1} \\
& R_{t+1}^{B_{i}}-R_{t}^{F}=\alpha+\beta_{1}\left(R_{t+1}^{V_{M}}-R_{t}^{F}\right)+\varepsilon_{t+1}
\end{aligned}
$$

where $R_{t+1}^{B_{i}}$ is bond portfolios returns, $R_{t}^{F}$ is the one-month T-Bill rate, $R_{t+1}^{M}$ and $R_{t+1}^{V_{m}}$ are aggregate equity and asset returns constructed using firms with asset return data available. We form 4-by-2-by-2 (time-tomaturity by credit ratings by priority) bond portfolios. The bond sample consists of nonfinancial firms with bond data available in the Lehman Brothers and EJV databases and also the CRSP and Compustat data available for the period from 1980 to 2007. The reported numbers are coefficient estimates, $R^{2}$, and the average numbers of securities in each portfolio. The column $H_{0}$ reports the difference in coefficients on $R_{t+1}^{M}$ in the first regression and $R_{t+1}^{V_{m}}$ in the third regression. The differences are estimated using GMM with an identity weighting matrix. $* * *$, and $* * *$ denote statistical significance at the 10,5 , and $1 \%$ levels. The numbers in parentheses are heteroskedasticity robust standard errors. The sample period is from 1980 to 2007. 


\begin{tabular}{|c|c|c|c|c|c|c|c|c|c|c|c|c|c|}
\hline \multirow[b]{2}{*}{ TTM } & \multirow[b]{2}{*}{ Priority } & \multicolumn{6}{|c|}{ Investment Grade } & \multicolumn{6}{|c|}{ High Yield } \\
\hline & & $R^{M}$ & $R^{V}$ & $R^{M}-R^{V}$ & $R^{2}$ & $N$ & $H_{0}$ & $R^{M}$ & $R^{V}$ & $R^{M}-R^{V}$ & $R^{2}$ & $N$ & $H_{0}$ \\
\hline \multirow[t]{6}{*}{$2-5$ yrs } & High & $\begin{array}{l}0.06^{* * * *} \\
(0.02)\end{array}$ & & & $6.7 \%$ & 471 & $\begin{array}{c}0.02 \\
(0.01)\end{array}$ & $\begin{array}{c}0.17^{* * * *} \\
(0.06)\end{array}$ & & & $11.8 \%$ & 165 & $\begin{array}{c}0.05 \\
(0.01)\end{array}$ \\
\hline & & & $\begin{array}{l}0.33^{\text {**** }} \\
(0.07)\end{array}$ & $\begin{array}{c}-0.92^{* * *} \\
(0.25)\end{array}$ & $16.3 \%$ & & & & $\begin{array}{l}0.59^{* * * *} \\
(0.10)\end{array}$ & $\begin{array}{c}-1.73^{* * *} \\
(0.37)\end{array}$ & $18.1 \%$ & & \\
\hline & & & $\begin{array}{c}0.09^{* * * *} \\
(0.02)\end{array}$ & & $8.0 \%$ & & & & $\begin{array}{c}0.22^{* * * *} \\
(0.07)\end{array}$ & & $13.0 \%$ & & \\
\hline & Low & $\begin{array}{l}0.06^{* * * *} \\
(0.02)\end{array}$ & & & $6.4 \%$ & 471 & $\begin{array}{c}0.02 \\
(0.01)\end{array}$ & $\begin{array}{l}0.17^{* * * *} \\
(0.06)\end{array}$ & & & $8.2 \%$ & 165 & $\begin{array}{c}0.05 \\
(0.02)\end{array}$ \\
\hline & & & $\begin{array}{c}0.32 * * * \\
(0.07)\end{array}$ & $\begin{array}{c}-0.90^{* * * *} \\
(0.24)\end{array}$ & $15.6 \%$ & & & & $\begin{array}{c}0.62^{* * * *} \\
(0.15)\end{array}$ & $\begin{array}{c}-1.86^{* * * *} \\
(0.72)\end{array}$ & $13.3 \%$ & & \\
\hline & & & $\begin{array}{c}0.0 * * * 9 \\
(0.02)\end{array}$ & & $7.7 \%$ & & & & $\begin{array}{c}0.22^{* * * *} \\
(0.08)\end{array}$ & & $9.1 \%$ & & \\
\hline \multirow[t]{6}{*}{$5-8$ yrs } & High & $\begin{array}{l}0.09^{* * * *} \\
(0.03)\end{array}$ & & & $5.9 \%$ & 281 & $\begin{array}{c}0.04 \\
(0.01)\end{array}$ & $\begin{array}{l}0.29^{* * * *} \\
(0.06)\end{array}$ & & & $22.6 \%$ & 167 & $\begin{array}{c}0.08 \\
(0.01)\end{array}$ \\
\hline & & & $\begin{array}{c}0.58 * * * \\
(0.11)\end{array}$ & $\begin{array}{c}-1.68 * * * \\
(0.38)\end{array}$ & $19.0 \%$ & & & & $\begin{array}{c}0.96^{* * * *} \\
(0.15)\end{array}$ & $\begin{array}{c}-2.74^{* * *} \\
(0.56)\end{array}$ & $33.3 \%$ & & \\
\hline & & & $\begin{array}{c}0.13 * * * \\
(0.04)\end{array}$ & & $7.4 \%$ & & & & $\begin{array}{c}0.37^{* * * *} \\
(0.07)\end{array}$ & & $24.6 \%$ & & \\
\hline & Low & $\begin{array}{l}0.11^{* * * *} \\
(0.03)\end{array}$ & & & $8.8 \%$ & 281 & $\begin{array}{c}0.04 \\
(0.01)\end{array}$ & $\begin{array}{l}0.31^{* * * *} \\
(0.06)\end{array}$ & & & $20.2 \%$ & 167 & $\begin{array}{c}0.08 \\
(0.02)\end{array}$ \\
\hline & & & $\begin{array}{c}0.53 * * * \\
(0.10)\end{array}$ & $\begin{array}{c}-1.44 * * * \\
(0.38)\end{array}$ & $19.4 \%$ & & & & $\begin{array}{l}0.96^{* * *} \\
(0.17)\end{array}$ & $\begin{array}{c}-2.64^{* * *} \\
(0.75)\end{array}$ & $28.7 \%$ & & \\
\hline & & & $\begin{array}{c}0.15 * * * \\
(0.03) \\
\end{array}$ & & $10.3 \%$ & & & & $\begin{array}{c}0.39^{* * * *} \\
(0.07)\end{array}$ & & $21.9 \%$ & & \\
\hline \multirow[t]{6}{*}{$8-15$ yrs } & High & $\begin{array}{l}0.14^{* * * *} \\
(0.04)\end{array}$ & & & $8.1 \%$ & 365 & $\begin{array}{c}0.06 \\
(0.01)\end{array}$ & $\begin{array}{l}0.37^{* * * *} \\
(0.07)\end{array}$ & & & $22.5 \%$ & 200 & $\begin{array}{c}0.10 \\
(0.01)\end{array}$ \\
\hline & & & $\begin{array}{c}0.79 * * * \\
(0.14)\end{array}$ & $\begin{array}{c}-2.25 * * * \\
(0.48)\end{array}$ & $22.0 \%$ & & & & $\begin{array}{l}1.33^{* * * *} \\
(0.20)\end{array}$ & $\begin{array}{c}-4.00^{* * *} \\
(0.80)\end{array}$ & $36.6 \%$ & & \\
\hline & & & $\begin{array}{c}0.20 * * * \\
(0.05)\end{array}$ & & $9.8 \%$ & & & & $\begin{array}{c}0.47^{* * *} \\
(0.09)\end{array}$ & & $24.8 \%$ & & \\
\hline & Low & $\begin{array}{l}0.13^{* * * *} \\
(0.03)\end{array}$ & & & $7.2 \%$ & 365 & $\begin{array}{c}0.05 \\
(0.01)\end{array}$ & $\begin{array}{l}0.36^{* * * *} \\
(0.07)\end{array}$ & & & $22.6 \%$ & 200 & $\begin{array}{c}0.09 \\
(0.02)\end{array}$ \\
\hline & & & $\begin{array}{c}0.75^{* * * *} \\
(0.13)\end{array}$ & $\begin{array}{c}-2.13^{* * *} \\
(0.45)\end{array}$ & $20.7 \%$ & & & & $\begin{array}{l}1.06^{* * * *} \\
(0.18)\end{array}$ & $\begin{array}{c}-2.83^{* * *} \\
(0.83)\end{array}$ & $30.6 \%$ & & \\
\hline & & & $\begin{array}{c}0.18 \\
(0.04) \\
\end{array}$ & & $8.8 \%$ & & & & $\begin{array}{l}0.45^{* * *} \\
(0.09)\end{array}$ & & $24.4 \%$ & & \\
\hline \multirow[t]{6}{*}{$\begin{array}{c}15 \text { yrs } \\
\text { or longer }\end{array}$} & High & $\begin{array}{l}0.18^{* * * *} \\
(0.05)\end{array}$ & & & $7.8 \%$ & 348 & $\begin{array}{c}0.07 \\
(0.02)\end{array}$ & $\begin{array}{c}0.17^{* * * *} \\
(0.08)\end{array}$ & & & $6.3 \%$ & 85 & $\begin{array}{c}0.06 \\
(0.02)\end{array}$ \\
\hline & & & $\begin{array}{c}1.11 * * * \\
(0.17)\end{array}$ & $\begin{array}{c}-3.23^{* * * *} \\
(0.60)\end{array}$ & $25.2 \%$ & & & & $\begin{array}{c}0.95^{* * * *} \\
(0.17)\end{array}$ & $\begin{array}{c}-3.37^{* * * *} \\
(0.58)\end{array}$ & $18.3 \%$ & & \\
\hline & & & $\begin{array}{c}0.25 * * * \\
(0.06) \\
\end{array}$ & & $9.7 \%$ & & & & $\begin{array}{c}0.23^{* * * *} \\
(0.09)\end{array}$ & & $7.4 \%$ & & \\
\hline & Low & $\begin{array}{l}0.19^{\text {***** }} \\
(0.04)\end{array}$ & & & $9.7 \%$ & 348 & $\begin{array}{c}0.08 \\
(0.02)\end{array}$ & $\begin{array}{l}0.29^{* * * *} \\
(0.09)\end{array}$ & & & $10.7 \%$ & 85 & $\begin{array}{c}0.08 \\
(0.03)\end{array}$ \\
\hline & & & $\begin{array}{l}1.11^{* * * *} \\
(0.16)\end{array}$ & $\begin{array}{c}-3.18^{* * *} \\
(0.54)\end{array}$ & $28.3 \%$ & & & & $\begin{array}{l}1.05^{* * *} \\
(0.23)\end{array}$ & $\begin{array}{c}-3.17^{* * *} \\
(0.97)\end{array}$ & $17.4 \%$ & & \\
\hline & & & $\begin{array}{c}0.27^{* * * *} \\
(0.05)\end{array}$ & & $11.9 \%$ & & & & $\begin{array}{c}0.37^{* * * *} \\
(0.12)\end{array}$ & & $11.8 \%$ & & \\
\hline
\end{tabular}

